\title{
Techniques and Rules of Ineffability in the Dionysian Corpus
}

\author{
Timothy D. Knepper
}

Associate Professor of Philosophy, Drake University, USA

e-mail: tim.knepper@drake.edu

\begin{abstract}
:
Is the Dionysian God, or an experience of the Dionysian God, absolutely ineffable? Does the Dionysian corpus assert or perform such ineffability? This paper will argue that the answer to each of these questions is no. The Dionysian God is known hyper-nous as the hyper-ousia cause of all. And the Dionysian corpus unambiguously refers to, asserts of, and metaphorizes about this God just so. In arguing these points, this paper will call upon both the speech act theory of John Searle and the metaphor theory of George Lakoff and Mark Johnson. More particularly, it will look to Searle's rules of reference and predication and conditions of illocutionary acts, as well as Lakoff and Johnson's schematization of metaphor gestalt and entailment to show how Dionysian expressions of inexpressibility are rule-governed and the Dionysian God is thereby (relatively) effable.
\end{abstract}

Keywords: Dionysius Areopagites, speech acts, Orthodox Christianity

This paper was first published in the volume

Schumann A. (ed), Logic in Orthodox Christian Thinking. Ontos Verlag, 2013, pp. 122-173.

Is the Dionysian God, or an experience of the Dionysian God, absolutely ineffable? ${ }^{1}$ Does the Dionysian corpus assert or perform such ineffability? This paper will argue that the answer to each of these questions is no. The Dionysian God is known hyper-nous as the hyper-ousia cause of all. And the Dionysian corpus unambiguously refers to, asserts of, and metaphorizes about this God just so. In arguing these points, this paper will call upon both the speech act theory of John Searle and the metaphor theory of George Lakoff and Mark Johnson. More particularly, it will look to Searle's rules of reference and predication and conditions of illocutionary acts, as well as Lakoff and Johnson's schematization of metaphor gestalt and entailment to show how Dionysian expressions of inexpressibility are rule-governed and the Dionysian God is thereby (relatively) effable. $^{2}$

Such arguments go against the grain of Dionysian studies. They therefore require a good deal more exegetical and dialectical work than a single essay can accomplish. Given this spatial constraint, this paper opts for breadth over depth. The goal here cannot be that of conclusively demonstrating any one set of rules through fine-combed exegesis of all the textual evidence. Instead, this paper seeks to sketch an overall picture of Dionysian expressions of inexpressibility, one that layers the rules of Dionysian illocutionary acts upon rules of Dionysian referring and predicating expressions, and upon all of these, rules of Dionysian metaphor systems. The paper therefore aims to produce a cumulative case argument for the relative effability of the Dionysian God. 


\section{Expressions of Inexpressibility within the Speech Act}

This first section of the paper identifies and analyzes Dionysian expressions of inexpressibility within the speech act, more specifically within referring and predicating expressions. It focuses on two such grammatical techniques: hypernames, the identification of hyper-prefixed divine names with God; and negation, the negation of divine names of God. It asks whether these techniques are governed by Searle's rule of reference and predication. And it answers that they are so governed, concluding that the Dionysian God therefore is relatively effable.

It is the simplicity of Searle's theories of reference and predication that make them so useful for the identification and analysis of ineffability discourse within the speech act. In the case of acts of singular definite reference, the referring expression itself must contain an identifying description that serves to pick out or identify the object in question (or the speaker must be able to produce such an identifying description on demand $)^{3}[25$, p. 88$]$.

(1) [Referring expression] $\mathrm{R}$ is to be uttered only in the context of a sentence (or some similar stretch of discourse) the utterance of which could be the performance of some illocutionary act;

(2) $\mathrm{R}$ is to be uttered only if there exists an object $\mathrm{X}$ such that either R contains an identifying description of $\mathrm{X}$ or [the speaker] $\mathrm{S}$ is able to supplement $\mathrm{R}$ with an identifying description of $\mathrm{X}$, and such that, in the utterance of $\mathrm{R}, \mathrm{S}$ intends to pick out or identify $\mathrm{X}$ to [the hearer] $\mathrm{H}$;

(3) The utterance of $\mathrm{R}$ counts as the identification or picking out of $\mathrm{X}$ to (or for) $\mathrm{H}^{4}$ [25].

And in the case of predication, the predicate expression must count as raising the question of its truth or falsity with respect to the object referred to by the referring expression (in the mode of the utterance's illocutionary force) [25, pp. 122-124].

(1) P [predicate expression] is to be uttered only in the context of a sentence or other stretch of discourse $\mathrm{T}$ the utterance of which could be the performance of some illocutionary act;

(2) $\mathrm{P}$ is to be uttered in $\mathrm{T}$ only if the utterance of $\mathrm{T}$ involves a successful reference to [object] X;

(3) $\mathrm{P}$ is to be uttered only if $\mathrm{X}$ is of a type or category such that it is logically possible for $\mathrm{P}$ to be true or false of $\mathrm{X}$;

(4) The utterance of $P$ counts as raising the question of the truth or falsity of $P$ of $X$ (in a certain illocutionary mode determined by the illocutionary device of the sentence) [25, p 127].

With these rules this paper will ask whether the Dionysian corpus successfully refers to and predicates of a God that is therefore not (absolutely) ineffable. ${ }^{5}$

One of the more prevalent and important ways in which the Dionysian corpus expresses

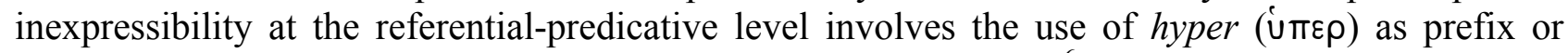
preposition. Not only is hyper ubiquitous in the Dionysian corpus; ${ }^{6}$ it is considered by some to be "the key to the central dialectic in Dionysian thought" [3, p. 193]. The very opening line of the Mystical Theology hymns the Trinity as hyper-being and hyper-god and hyper-good (MT 1.1,

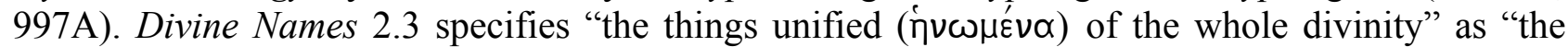
hyper-good, the hyper-god, the hyper-being, the hyper-life, and the hyper-wise and whatever else is of the hyper-having removal ( Names 11.6 informs the reader that when Dionysius speaks of God as "that which gives substance 
(üтобтর́тฺv) to life-itself or peace or power" (rather than as life-itself or peace-itself or poweritself), he does so "as hyper-beingly hyper-be-ing hyper all and the first beings" (DN 11.6, 953BC). What does the Dionysian corpus mean in referring to and predicating of God with such hypernames?

Given the usual translation of hyper as beyond, scholars generally read these hypernames as indicating transcendence beyond the name that has been hyper-prefixed. But Liddell and Scott's Greek-English Lexicon suggests that when hyper is used with respect to place and measure, it can be translated not only as beyond but also as over, above, and exceeding:

1. with respect to place in reference to motion: over, beyond;

2. with respect to measure: above, exceeding, beyond;

3. with respect to number: above, upwards;

4. with respect to time: beyond (i.e., before, earlier than);

5. in some dialects: on behalf of, concerning [16, p. 1858].

As is the case with most prepositions, these different meanings reflect different spatial relations, two of which are principal here: a sense of being beyond or across something (horizontal distance), and a sense of being over or above something (vertical height). And these two different spatial relations convey two different logical meanings: in the first case, the complete inapplicability or falsity of that which one is beyond or across; in the second case, an excessive measure or manner of that which one is over or above. Moreover, these two different logical meanings suggest two different senses of transcendence: removal beyond and superiority above. ${ }^{7}$

And it is not merely the case that hyper itself is grammatically ambiguous; it is also the case that the Dionysian corpus deploys hypernames ambiguously, sometimes to stress preeminence above; other times, removal beyond; and rarely to mean one to the exclusion of the other. Divine Names 4.3, for example, is not clear about whether hyper-prefixed and alpha-privative divine names, when said of the hyper-being good, denote excess above or exceeding beyond the name in question.

If the good is hyper all beings, as it is, the formless produces-form. And in it alone non-being ('́์

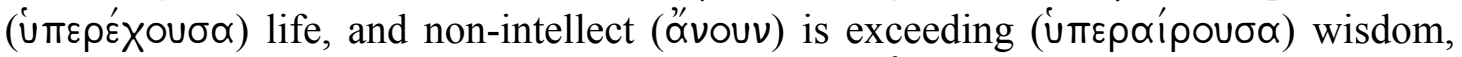

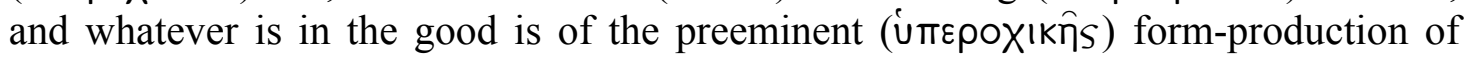
that which is formless. And, if it is lawful to say, non being ( $\mu \eta \underline{o} v)$ itself desires the good hyper all beings, and strives somehow to be in the good, and is truly hyper-being

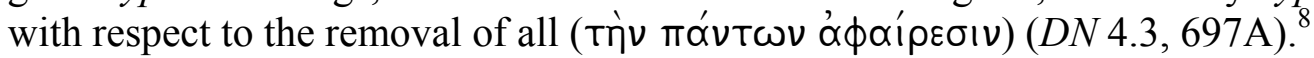

And Mystical Theology 1.1 uses several different hyper-light variations, each of which is ambiguous between a superabundant excess of light and a complete removal beyond light (thereby rendering the first three hyper-prefixed names ambiguous as well).

Trinity hyper-being and hyper-god and hyper-good, overseer of Christians in divine

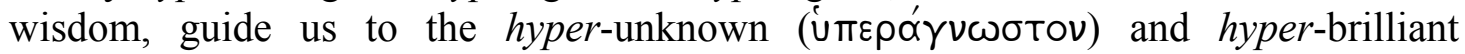
( $(\pi \varepsilon \rho \phi \alpha \hat{\eta})$ highest summit of mystical scripture; there the simple, absolute, and

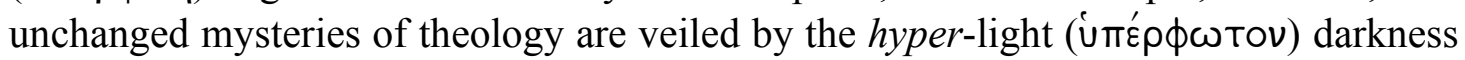

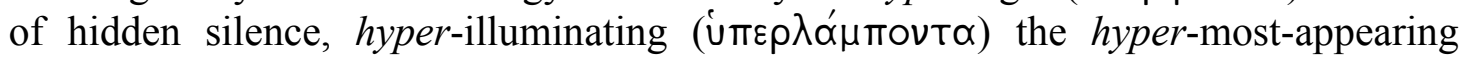

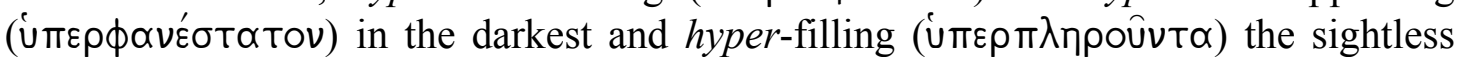

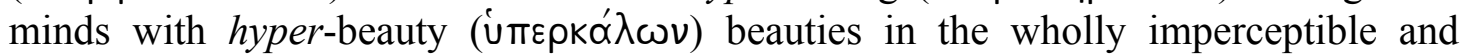
invisible (MT 1.1, 997B). 
What does this ambiguity entail for an analysis of the grammatical technique of hypernames as an expression of inexpressibility? Provisionally, it suggests that hypernames frustrate reference and predication in not one or two but three different ways. Read as significations of excessive measure, hypernames fail both to refer to and predicate of God insofar as they attribute to God some property in excess of its greatest possible degree. It is crucial here to understand this: taken excessively, hypernames are not mere superlatives; they are super-superlatives that immeasurably exceed the maximum possible (superlative) degree. With respect to some divine name $d n$ they indicate that God is more-dn-than-maximum- $d n .^{9}$ Hypernames therefore fail both to refer to and to predicate of God for the simple reason that, according to the grammatical logic of comparatives and superlatives, something cannot possess more of some attribute than the greatest possible measure of that attribute. Such more-dn-than-maximum- $d n$ phrases therefore cannot serve as either individuating identifying descriptions or logically possible categories. And if we read hypernames as significations of utter inapplicability, then they fail to refer to and predicate of God for a different and simpler reason. In this case hypernames indicate that the divine name in question simply does not count as an identifying description or predicate term since the object of reference and subject of predication is entirely beyond it - they signify, with respect to some divine name $d n$, that God is beyond- $d n$. Moreover, when such hypernames are conjoined in rapid succession they imply that no divine name may count as an identifying description or predicate term of God, that God is beyond the domain of all differentiation and therefore cannot be identified or predicated as anything - they signify that God is beyond-all-dn. And it is by virtue of the ambiguity between these two interpretations that hypernames ostensibly frustrate reference and predication in a third way: if hypernames do not at all apply to God, then God cannot possess them in excessive superabundance; but if God possesses them in excessive superabundance, then God cannot be utterly beyond them. Such a contradiction obviously renders hypernames unsuitable as both identifying descriptions that unambiguously identify and predicate terms that are logically possible. It is therefore necessary to turn to a second referential-predicative technique to resolve this ambiguity.

This second, very prevalent, very important means by which Dionysius expresses inexpressibility at the referential-predicative level is negation. It is crucial immediately to observe, though, that there are two principal terms for and types of negation in the Dionysian corpus: aphairesis (removal), a method of removing predicate-terms; and apophasis (negation), a logic for interpreting predicate-terms preeminently rather than privatively. ${ }^{10}$ And it is important next to note that the former is employed much more frequently than the latter: whereas aphairesis/aphairo shows up a total of twenty-six times in the corpus, apophasis/apophaskō makes just eight appearances, only two of which can be found in the "apophatic" treatise Mystical Theology, neither of which falls after the introductory chapter. ${ }^{11}$ The term apophasis is therefore entirely absent from the central methodological and performative chapters of the Mystical Theology (while aphairesis is used twelve times in these chapters and fourteen times in the entire treatise). Instead, the chapters on method (chs. 2-3) present aphairesis as the privileged means of hymning the hyper-being God, and the subsequent performative chapters (chs. 4-5) implement this method, hymning the hyperbeing God through the removal of perceptible and intelligible properties from God. Together these chapters present the following picture of aphairesis. Aphairesis hymns God by removing "beings" from it. Aphairesis removes these beings sequentially, from last or furthest to first or closest: first alpha-privative prefixed intelligible properties (e.g., being-less, life-less), then sensible properties, then intelligible and trinitarian properties, and finally properties pertaining to thinking and speaking about God. Aphairesis removes such predicate-terms by means of narrow-scope predicate-term negation in which negative particles precede and therefore apply to the predicate-terms alone (rather than the entire predicate). ${ }^{12}$ And aphairesis removes "all" beings from God, yet paradoxically reveals an underlying "statue," thereby yielding true "knowing" and "seeing" of the unknowable divine darkness. 
We pray to come to this hyper-light darkness, and through not-seeing and not-knowing to see and to know not to see and to know that which is hyper sight and knowledge itself - for this is truly seeing and knowing - and [we pray] to hymn hyper-beingly the hyper-being through the removal of all beings (

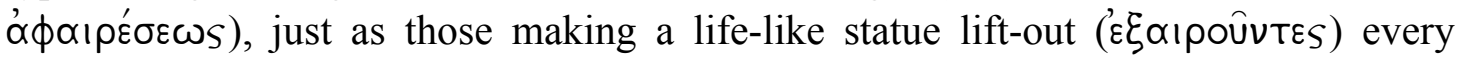
obstacle to the pure view of the hidden and reveal the hidden beauty in it by the

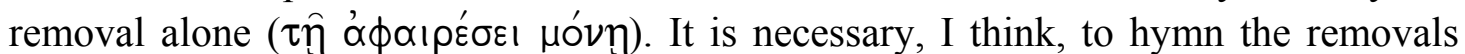

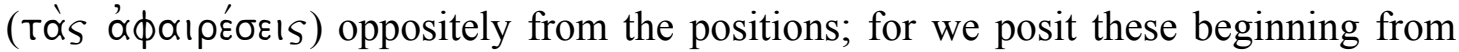
the first things and descending through the middle things to the last things; but then

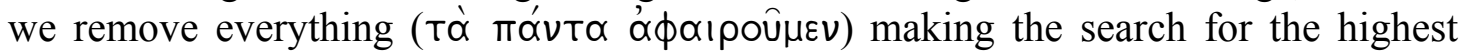
principles from the last things, so that we may unhiddenly know this unknowing that is covered by all the knowledge among all beings, and we may see this hyper-being darkness that is hidden by all the light among beings (MT 2, 1025AB).

When apophasis does make its appearances in the Dionysian corpus, it does so not as a method of negating predicate-terms but as a logic of interpreting negative predicate-terms "hyperochically" (preeminently) rather than "steretically" (privatively). This understanding of apophasis comes out particularly well when several of the passages in which it appears are read together. According to Celestial Hierarchy 2.3, apophatic predicate-terms such as invisible, infinite, and inseparable signify not what God is but what God is not. In hymning God as invisible, the theologians deny that God possesses the attribute of visibility (with respect to being) rather than affirming that God possesses the attribute of invisibility.

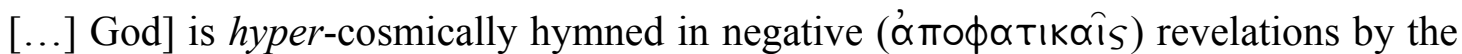

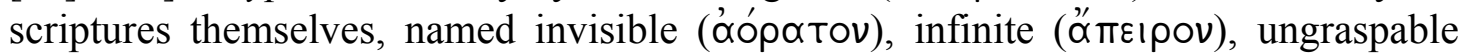

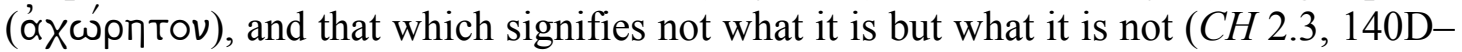
141A).

Divine Names 7.1 then furthers this, asserting that apophatic predicate-terms such as invisible, ineffable, unnamable, incomprehensible, and inscrutable indicate not God's lack but God's excess. In calling God invisible, the theologians attest to God's abounding luminosity (i.e., all-shining light) rather than God's deprivation of (ordinary) visibility: God is invisible in the sense that God is other than (ordinary) visibility qua excessive or exceeding visibility.

[...] it is customary for theologians to negate ('̊

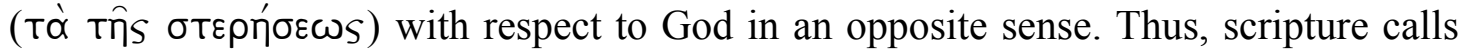
the all-shining light invisible (áóparóv), and the many-hymned and many-named

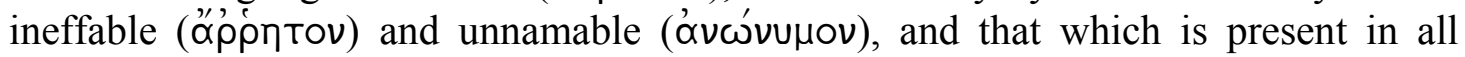
things and discoverable from all things incomprehensible and inscrutable ( $D N$ 7.1, 865BC).

And Epistle 4 maintains that affirmations about Jesus' love for humanity have the power of preeminent negation (hyperochikēs apophaseōs). In saying that Jesus was non-human, we maintain that Jesus is hyperoche or hyper human: Jesus is not-human in the sense that Jesus is other than (ordinary) humanity qua excessive or exceeding humanity.

Why should one go through the remaining things, which are numerous? Through them the one who sees divinely will know hyper mind that the affirmations

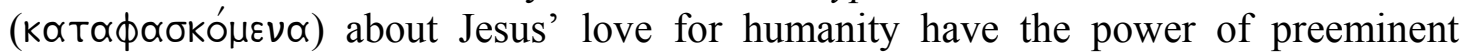

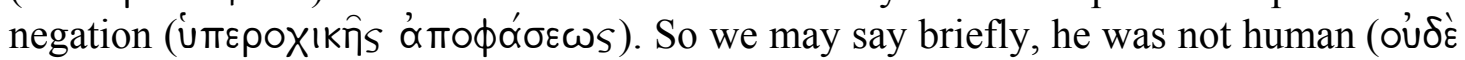




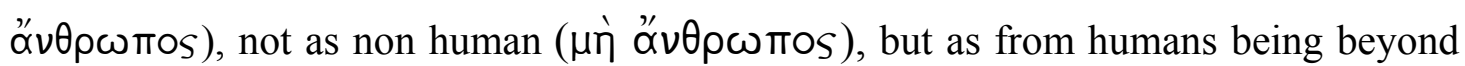
humans and as hyper human having truly become human, and, as for the rest, not having done the things of God as God, nor the things of humans as human, but administering for us a new theandric activity as God having become human (EP 4, 1072BC). ${ }^{13}$

Two phrases are here of crucial significance. The first, to negate the things of privation, states that apophatic negation must be sharply differentiated from privative negation (steresis, or less commonly elleipsis). The second, preeminent negation, shows that this difference must be understood semantically - apophatic negation states preeminence (hyperochē), not privation (steresis). Thus "negating the things of privation" does not change the syntactic form of a predicateterm negation (which can be of either the alpha-privative (unwise) or indefinite (not-wise) variety). Rather, it indicates that the predicate-term negation in question should be interpreted preeminently rather than privatively. And as passages such as Divine Names 7.2 suggest, when negative predicate-terms are applied to God, we should always interpret them preeminently rather than privatively.

But as I have often said, one must intellect the divine divinely. For one must arrange

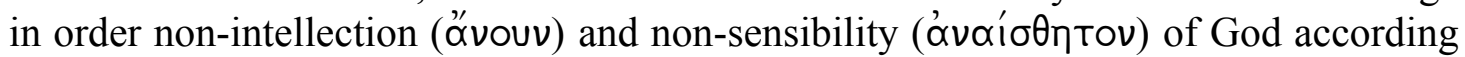

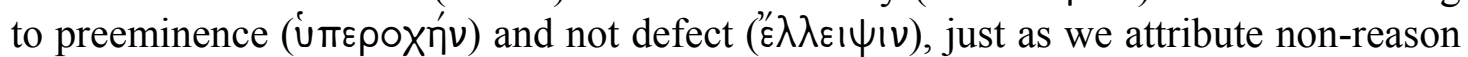

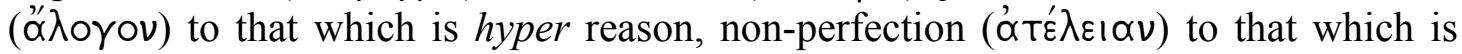
hyper-perfection and pro-perfection, and non-manifest ( $\dot{\alpha} \nu \alpha \phi \hat{\eta})$ and non-visible

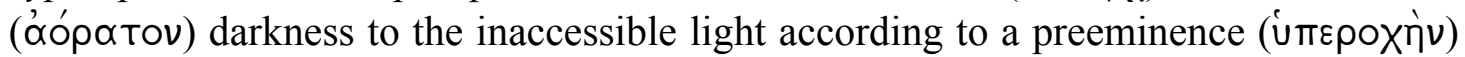
of visible light (DN 7.2, 869A; Cf., EP 1, 1065A).

Taken together, all of these passages in general and both of these phrases in particular reveal Dionysius' apophatic logic of negation: negative predicate-terms, read apophatically, indicate preeminence rather than privation. To say that God is not some divine name is to say not that God is lacking some divine name but that God preeminently possesses some divine name.

One could initially say therefore that aphairesis and apophasis are referentiallypredicatively troublesome in opposing ways: whereas aphairesis turns away identifying descriptions and predicate-terms, thereby effectively refusing to identify and predicate anything of God (beyond-dn), apophasis identifies and predicates an excessive measure of divine names of God, thereby associating problematic identifying descriptions and predicate-terms with God (more$d n$-than-maximum-dn). But there are two difficulties with such a neat reading. On the one hand, apophasis interprets that which aphairesis removes - the identifying descriptions and predicateterms that aphairesis turns away are to be interpreted apophatically. ${ }^{14}$ (To put it in the above imagery of the statue, the aphairetic removal of all beings reveals an underlying apophatichyperochic statue. ${ }^{15}$ ) On the other hand, apophatic interpretation is hyperochic, where a sense of preeminent-having is balanced by a sense of beyond-having. (This is so since hyperoche is composed of the preposition hyper and the verb to have (echō), and the preposition hyper is ambiguous between preeminent excess and exceeding beyond. ${ }^{16}$ ). At second blush, therefore, Dionysian negation appears to be referentially-predicatively troublesome in the same three ways as Dionysian hypernames. But in fact it is hyperoche that provides the key to resolving this ambiguity in general and to demonstrating how to refer to and predicate of the Dionysian God in particular.

If the Dionysian corpus deploys hyperoche at all like other Neoplatonists did, then it means by it the preeminence of causes over their effects (see [16], [11]). This is not to say that causes participate in their effects but rather that causes pre-exist and therefore pre-contain their effects. This, the Dionysian corpus tells us several times. ${ }^{17}$ But what it tells us more often is that it is the divine-names-themselves that are the causes of the properties they effect: life-itself is the cause of 
the property of life; being-itself, the cause of being. ${ }^{18}$ And what it never tells us is that God is not cause of all things. ${ }^{19}$ Put all this together and this is what you get: God is the cause of all things by means of his divine names; these divine-names-themselves pre-exist and pre-contain the properties that they source (in a manner that is hyper-unified and hyper-existent); these divine-namesthemselves do not participate in the properties that they source. Add to this what we now know about Dionysian negation and the following picture emerges: to interpret apophatic predicate-terms hyperochically is to see that aphairesis removes from God the divine names qua properties to reveal a hyper-being God that pre-contains the divine names, which themselves pre-contain their effects. Combine this with what we know about Dionysian hypernames and the picture gets clearer: hyperprefixed divine names function to indicate both that God is completely beyond the divine names qua effects (which are things of being) and that God preeminently possesses the divine names qua causes (which are hyper-being). Put differently, God is not the divine names insofar as God does not participate in the properties that they source, but God is divine names themselves as the hyperunified, hyper-existent sources of these properties.

This disambiguation makes good sense of the evidence already presented - apophatic interpretation is hyperochic not steretic, hyperoche registers both transcendence and preeminence, the Dionysian God is the cause of all, divine names themselves are divine causal powers, divine names themselves are pre-contained in God, divine names themselves are hyper-unified and hyperexistent, divine names themselves are not removed from God, ${ }^{20}$ the properties that divine names themselves source are pre-contained in the divine names themselves in a hyper-unified manner, and so on. This disambiguation also makes good sense of the evidence yet to be presented - that the hyper-ousia God may be known hyper-nous, and that this God dwells on an enshrouded divine summit that may be ascended. But here I will argue that this disambiguation makes good sense of the grammatical-logical form of aphairetic removal. As indicated above, the logical form of Dionysian negation is narrow-scope predicate-term negation, which, according to Aristotle fails to obey the law of the excluded middle just in case either the referring expression is vacuous or the predicate expression is a category mistake. This means that, if mind is a category mistake of God, then there is no contradiction when Dionysius asserts at the beginning of Mystical Theology 4 that God is not mind-less and then later asserts in Mystical Theology 5 that God is not mind. But it means more, since it is not the middle but the non-middle that Dionysius excludes. ${ }^{21}$ Both mind and mind-less are false of God since God is hyper or hyperoche mind. And God is hyper or hyperoche mind as the cause of mind, the hyper-unified and hyper-existent divine name mind-itself that precontains its effects. ${ }^{22}$

The Dionysian God can therefore be unambiguously identified and logically predicated as, on the one hand, the hyper-being cause of all, the source of the properties in which beings participate, and on the other hand, not itself a being, utterly beyond the things of being. The Dionysian techniques of hypernames and negation are therefore governed by the following rules:

- Dionysian Rule of Reference: God is properly identified as that which cannot be identified by anything of being (i.e., the properties sourced by the divine names themselves), but possesses of everything of being in hyper-being preeminence (i.e., precontains the properties sourced by the divine names themselves).

- Dionysian Rule of Predication: God is properly predicated as that which cannot be predicated by anything of being (i.e., the properties sourced by the divine names themselves), but possesses everything of being in hyper-being preeminence (i.e., precontains the properties sourced by the divine names themselves).

These rules constitute an intra-textual logic or grammar, regulating Pseudo-Dionysius' otherwise antinomian techniques of reference and predication. These rules show that the Dionysian God is not absolutely ineffable. 


\section{Expressions of Inexpressibility at the Speech Act}

This second section of the paper identifies and analyzes Dionysian expressions of inexpressibility at the level of the speech act, more specifically with respect to illocutionary force. It focuses on two such grammatical techniques: assertions of ineffability and directions of ineffability. It asks whether these techniques are governed by Searle's conditions of illocutionary force. And It answers that they are so governed, concluding that the Dionysian God therefore is relatively effable.

Searle's theory of illocutionary force rests upon the simple yet revolutionary insight that the speech act is "the basic or minimal unit of linguistic communication". [25, p. 16] Every saying is a doing; every speech act therefore contains not only some propositional content $(p)$ that is said but also some illocutionary force $(F)$ that is done. One motivation for this distinction, according to Searle, is that it enables us "to account for and represent the generally overlooked distinction between illocutionary negation and propositional negation": while in most cases negation is of propositional content alone (e.g., it's not raining), in some cases negation is instead of illocutionary force (e.g., I don't say it's raining) or even of both propositional content and the illocutionary force (e.g., I don't say it's not raining). [25, p. 32] Another motivation, one that is of particular use in the identification and analysis of antinomian illocutionary techniques, is that the distinction between illocutionary force and propositional content enables an analysis of the conditions of successful illocutionary acts. These include not only an essential condition, which concerns what the speaker does (overall illocutionary point), and a propositional content condition, which concerns what the speaker says, but also a preparatory condition, which pertains to what the speaker implies, and a sincerity condition, which pertains to what the speaker expresses. [25, pp. 66-67] These conditions therefore make possible an understanding of the ways in which illocutionary acts can be unsuccessful ("self-defeating"), the following five of which are itemized:

- The illocutionary point cannot be achieved on the propositional content (e.g., "All my assertions are false");

- The illocutionary point cannot be achieved with the required mode of achievement of F on the propositional content (e.g., "I order you to disobey all orders");

- The propositional content is inadequate (e.g., "I predict that John Paul the Second has been elected as Pope");

- The preparatory conditions are impossible to presuppose (e.g., "I promise to do it, and I cannot keep this promise");

- The psychological state is impossible to express (e.g., "I apologize for that course of action which benefited you") [26, pp. 151-152].

Here we have what is probably the most useful instrument for the identification and analysis of illocutionary techniques. Its use, though, obviously requires prior determination of the illocutionary force type of the speech act in question. And so, Searle's taxonomy of illocutionary force - which is derived from the primary criteria of illocutionary point, direction of fit, and expressed psychological state [23] - is also necessary: 
Table 1: Searle's Illocutionary Act Taxonomy

\begin{tabular}{|c|c|c|c|c|}
\hline & $\begin{array}{l}\text { Illocutionary } \\
\text { Point }\end{array}$ & $\begin{array}{l}\text { Direction } \\
\text { of Fit }\end{array}$ & $\begin{array}{l}\text { Psychological } \\
\text { State }\end{array}$ & $\begin{array}{l}\text { Propositional } \\
\text { Content }\end{array}$ \\
\hline Assertives & $\begin{array}{l}\text { Commit speaker to } \\
\text { truth of expressed } \\
\text { proposition }\end{array}$ & $\begin{array}{l}\text { Word-to- } \\
\text { world }\end{array}$ & Belief & Any proposition \\
\hline Directives & $\begin{array}{l}\text { Attempt by speaker } \\
\text { to get hearer to do } \\
\text { something }\end{array}$ & $\begin{array}{l}\text { World-to- } \\
\text { word }\end{array}$ & $\begin{array}{l}\text { Want, wish, } \\
\text { desire }\end{array}$ & $\begin{array}{l}\text { Future act of } \\
\text { hearer }\end{array}$ \\
\hline Commissives & $\begin{array}{l}\text { Commit speaker to } \\
\text { some future course } \\
\text { of action }\end{array}$ & $\begin{array}{l}\text { World-to- } \\
\text { word }\end{array}$ & Intention & $\begin{array}{l}\text { Future act of } \\
\text { speaker }\end{array}$ \\
\hline Expressives & $\begin{array}{l}\text { Express } \\
\text { psychological state } \\
\text { about a state of } \\
\text { affairs }\end{array}$ & None & $\begin{array}{l}\text { Range of } \\
\text { different } \\
\text { possible states }\end{array}$ & $\begin{array}{lr}\text { Some property } \\
\text { ascribed } & \text { to } \\
\text { speaker } & \text { or } \\
\text { hearer } & \\
\end{array}$ \\
\hline Declaratives & $\begin{array}{lrr}\text { Bring a state of } & \text { of } \\
\text { affairs } & \text { into } \\
\text { existence } & \text { by } \\
\text { declaring it so } & \end{array}$ & Both & None & Any proposition \\
\hline
\end{tabular}

Together Searle's taxonomy of illocutionary force, conditions of illocutionary force, and distinction between illocutionary and propositional negation prove of considerable use to the identification and analysis of Dionysian illocutionary techniques. ${ }^{23}$

The most obvious illocutionary technique used by Dionysius to convey the (relative) ineffability of God is a direct assertion that God is ineffable or hyper effable. As the previous sentence suggests, this technique comes in two basic forms, each of which possesses variations. The first form, the assertion that God is in some way ineffable, comes in two basic variations. In most cases Dionysius either asserts negative (alpha-prefixed) predicate-terms such as unnamable (anōnymos), ineffable (arrētos), unspeakable (aphthegktos), and logos-less (alogos) of God (or divine things) or denies positive predicate-terms such as name (onoma), speech (legō), and logos (logos) of God (or divine things). ${ }^{24}$ And in a couple of other cases Dionysius denies the methods of position (thesis) and removal (aphairesis) of God. ${ }^{25}$ These illocutionary techniques, especially those that fall in the last chapter of the Mystical Theology, play a crucial role in the Dionysius corpus, culminating the aphairetic removal of individual divine names by denying "all" thetic positioning of and aphairetic removing from God whatsoever. But whereas these techniques seem perfectly intelligible and successful on this account, they technically defeat themselves for at least two reasons: their illocutionary points of assertion cannot be achieved on their propositional contents of unassertability, and their preparatory conditions of evidence are impossible to presuppose. The claim that one cannot name and speak about God is itself a naming and speaking of God; the assertion that one cannot assert is itself an assertion; the removal of removal is itself a removal. Thus these propositional contents of unassertability cannot be realized on their illocutionary force of assertion. Moreover, these assertions presuppose evidence for their truth (regardless of whether the speaker is actually in possession of such evidence). But what evidence could one have for the ineffability of something, since all such evidence would require having at least some knowledge about what that thing is (even when that "thing" is no-thing or beyond-things)? The preparatory condition of evidence is therefore impossible to presuppose. ${ }^{26}$

Dionysius' second form of ineffability assertion is still more problematic as it is plagued by both of these difficulties as well as a couple of additional complications. Much like the assertion 
that God is ineffable, the assertion that God is hyper effable can take the form of an assertion that God is hyper name or word or speech as well as an assertion that God is hyper the methods of position and removal. ${ }^{27}$ But it can also take the form of an assertion that God is hyper-ineffable, an assertion that appears to be at odds with the assertion that God is hyper-effable. ${ }^{28}$ And on top of this, there is again the problem of determining how to translate and interpret these uses of hyper: when Dionysius says that God is hyper effability, hyper ineffability, and hyper both effability and ineffability, does Dionysius mean that God is beyond in/effability, more-in/effable-than-mostin/effable, or both?

But this added complication, the ambiguity of hyper, in fact provides a key to resolving all of these difficulties. To be such a key, though, the full (dual) resonance of hyper must be allowed to sound out. This is to say that although it is tempting to interpret these hyper-constructions in such a way as to make the Dionysian God beyond effability as exceedingly ineffable, this misses the fact that the Dionysian God is also beyond ineffability and exceedingly effable. And it also fails to provide a basis for Dionysius' assertion that God is ineffable. Both of these arguments require some explanation. Since the ineffability of something is always relative to some semiotic system in which that thing cannot be said, the ability to know and say that something is ineffable is only possible from the perspective of some other semiotic system. ${ }^{29}$ Put in Dionysian terms, if God is ineffable to beings, then this can only be known and said to be the case from some perspective that is not of being. This other perspective, in short, is the humanly (and angelically) unknowable realm of hyperbeing. Thus Dionysius' assertion that God is hyper both effability and ineffability functions on the one hand as indication that God is beyond both effability and ineffability, neither effable nor ineffable, from the perspective of being (since in/effability is a category mistake of God). But since this can only be known and said from a hyper-being perspective, Dionysius' assertion that God is hyper both effability and ineffability must on the other hand serve as pointer to this transcendent mode of "discourse." Here God is transcendently ineffable qua transcendently effable, moreineffable-than-most-ineffable as more-effable-than-most-effable. ${ }^{30}$

Granted, this is not the simplest of solutions. But it is the only one that provides a ground for Dionysius' claim that God is ineffable, and is therefore the only one that preserves a noncontradictory reading of Dionysius' assertions of unassertability, sayings of unsayabillity, and removals of removal. ${ }^{31}$ And it is the only solution that can explain - without resorting to hyperbole - those passages in the Dionysian corpus that speak of God's ineffability as transcendent namability or speakability and ineffable truth or logos. ${ }^{32}$

For just as intelligible things are incomprehensible and unseen to the senses, and uncompounded and unformed things [are incomprehensible and unseen] to that in shape and form, and the intangible and unstructured formlessness of bodiless things [are incomprehensible and unseen] to that which is formed according to the structure of bodies, then, according to the same analogy of truth, the hyper-being infinite lies above beings and the hyper mind unity lies above minds. The one hyper thought is

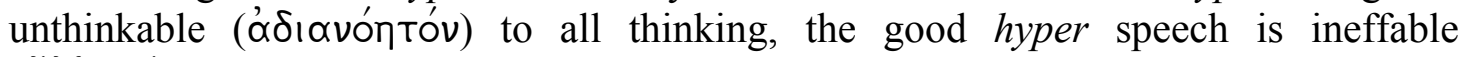
(áp'ṕptóv) to all speech, henad uniting every henad and hyper-being being and unintelligible (óvóntos) intellect and ineffable (áṕp’os) speech, speechlessness

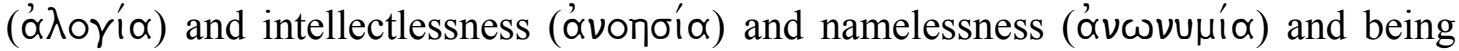
according to nothing of being and cause of all being, but itself not being as beyond all being so that it alone could properly and scientifically (' $\left.\varepsilon \pi ı \tau \eta \tau \omega \hat{S}_{S}\right)$ manifest itself about itself (DN 1.1, 588B).

On the one hand, [God is] nameless, since they say the godhead itself, in one of the mystical sights of the symbolic theophany, rebukes him who says "What is thy name?" and, leading him away from all knowledge of the divine names, says "Why do 
you ask my name?" and "It is most wondrous." Is not this truly the most wondrous

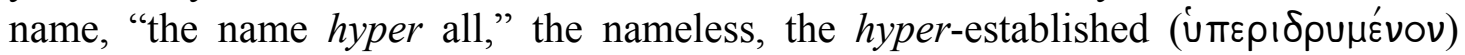
"every name that is named," whether in this age or in the future? (DN 1.6, 596A).

For example, this is unified and common to the henarchic trinity with respect to the divine unity hyper-beingness: the hyper-being subsistence, the hyper-divine divinity, the hyper-good goodness, the identity beyond all of the whole identity beyond all, the

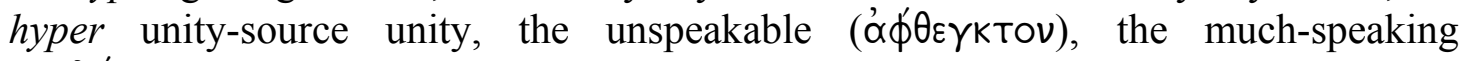
(moגú $\phi \omega \nu \circ v$ ), the unknowable, the all-intelligible, the position of all, the removal of all, the hyper all position and removal, the remaining and foundation of the henarchic substances in one another (if I may so speak), wholly hyper-unified, and in no part comingled, $[\ldots](D N 2.4,641 \mathrm{~A})$.

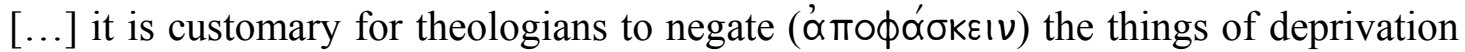

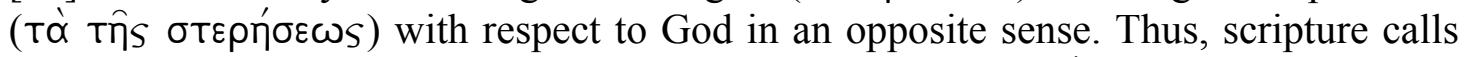

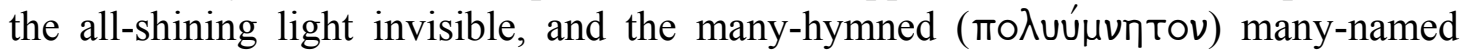

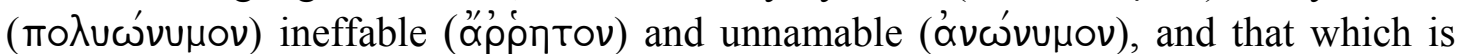
present in all things and discoverable from all things incomprehensible and inscrutable. In this way, even now, the divine apostle is said to have hymned as foolishness of God that which appears unreasonable and paradoxical in itself, but which uplifts us to the ineffable truth before all reason $(D N 7.1,865 \mathrm{BC})$.

It is also the only solution that resolves the first two illocutionary difficulties encountered above. If the assertion that God is ineffable is made from the perspective of hyper-being with respect to the things of being, then its propositional content can be realized on its illocutionary point and its preparatory conditions can be presupposed. God can be known and said to be ineffable in one "language" provided that this ineffability pertains to some other language. Of course, there is problem pertaining to how Dionysius, a being, could know and say that God is ineffable. But here, we can do as Dionysius does and appeal to revelation: Dionysius knows and can therefore say that God is ineffable since this has been revealed to Dionysius by God (through the celestial and ecclesiastical hierarchies by means of a hyper-logos "saying"). ${ }^{33}$ (Note, though, that Dionysius, a being, would not be able to know or say what this means - more on this later).

The Dionysian corpus is not always content simply to assert the ineffability of God. Occasionally Dionysius also directs his reader, or asks God to direct both himself and his reader, to an experience of divine ineffability and unknowability. Such illocutionary acts of ineffability direction are quite prevalent in the Mystical Theology, which opens by petitioning Trinity to guide

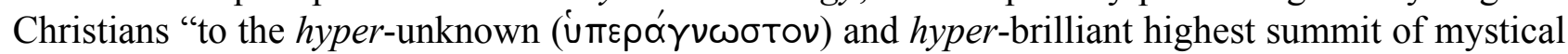
scripture;" then exhorts its reader, Timothy, both to "leave behind sensible and intellectual activities, all sensible and intelligible things, all non-beings and beings, and unknowingly strive upward, as far as possible, toward the union (" $\varepsilon \omega \omega \sigma \mid v)$ of that which is hyper all being and

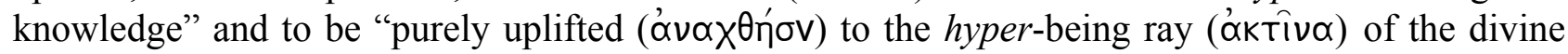
darkness;" and later directs the reader now to enter the hyper mind darkness of complete logos-lessness, unknowing, and soundless, and to become "wholly unite to the unspeakable ( $\propto \phi \theta \varepsilon \hat{\varepsilon} \gamma \kappa \omega \omega)$ " (MT 1.1, 997A-1000A; MT 3, 1033BC).

If Dionysius' ineffability assertions culminate the removal of individual divine names from God, then ineffability directions culminate ineffability assertions. Here the Dionysian corpus does more than just say that God is ineffable; it realizes ineffability, a state of silent unknowing. As was the case with Dionysius' ineffability assertions, however, these ineffability directions are ostensibly self-defeating. Since their propositional contents concern states that cannot be said and known, they are inadequate to their illocutionary forces of direction. One cannot be directed to strive toward that 
which is essentially unknowable and unsayable. Thus one of the preparatory conditions of these illocutionary acts of direction - ability to undertake the directed action ${ }^{34}$ - also cannot be presupposed. One cannot do that which cannot be known and said. Of course, it could be said that such a destination is not unknown to all, that God quite clearly "knows" what happens when one is guided into the divine darkness. And it could also be said that the destination would not itself have to be knowable and sayable (by humans) for the path to it to be effective (for humans). Still, though, there would be, as in the case of ineffability assertion, the problem of knowing and saying that some destination is unknowable and unsayable, for if that destination were really unknowable and unsayable then it could not be known and said to be a something that is unknowable and unsayable.

As was the case of ineffability assertion, however, a way out of this dilemma lies in Dionysius' use of the term hyper-unknowable, which, much like hyper-ineffable, registers not only a sense of being really unknowable but also a sense of being knowable in a preeminent or transcendent manner. ${ }^{35}$ Moreover, this solution is confirmed throughout the Mystical Theology, as several other passages reveal the destination of Dionysius' directions to be a state of both unknowing and knowing. The last sentence of chapter one describes it as one of knowing hyper mind by knowing nothing:

And then [Moses] is released from what sees and is seen and enters into the truly mystical darkness of unknowing, in which he shuts out every knowing apprehension and comes into the wholly intangible and invisible, being entirely of that which is beyond everything and nothing, neither himself nor another, united surpassingly

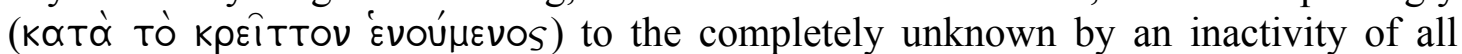
knowledge, knowing hyper mind by knowing nothing $(M T 1.3,1000 \mathrm{C}-1001 \mathrm{~A}){ }^{36}$

The final sentence of chapter two describes it as unhiddenly knowing the unknowing that is covered by all the knowledge among beings:

It is necessary, I think, to hymn the removals oppositely from the positions; for we posit these beginning from the first things and descending through the middle things to the last things; but then we remove everything making the search for the highest principles from the last things, so that we may unhiddenly know this unknowing that is covered by all the knowledge among all beings, and we may see this hyper-being darkness that is hidden by all the light among beings (MT 2, 1025B).

And the first sentence of chapter two "directs" God to conduct us to the hyper-light darkness in which true knowledge of the unknowable God is acquired by not-knowing to know not to know that which is hyper-knowledge:

We pray to come to this hyper-light darkness and through not-seeing and not-knowing to see and to know not to see and to know that which is hyper sight and knowledge itself - for this is truly seeing and knowing - and [we pray] to hymn hyper-beingly the hyper-being through the removal of all beings, just as those making a life-like statue lift-out every obstacle to the pure view of the hidden and reveal the hidden beauty in it by the removal alone (MT 2, 1025A).

If one takes unknowing and knowing to apply here in the same way and at the same time, these illocutionary acts, whether said with an assertive force or a directive force, are self-defeating. Their propositional contents are contradictory and therefore "inadequate" to their illocutionary forces. And their preparatory conditions - evidence, in the case of assertion; ability, in the case of direction - are therefore impossible to presuppose. But if unknowing and knowing apply to this destination or state in different respects, then the former of these objections disappears: God 
transcends all ordinary modes of knowing yet is known through a transcendent mode of knowing; God is unknowable from the perspective of being yet known from the perspective of hyper-being. Moreover, if such knowledge about unknowing knowing is not only revealed by God (through the celestial and ecclesiastical hierarchies) but also experientially realized while in a state of unknowing knowing, then the latter of these objections also disappears. And here, unlike the case of ineffability assertion, Dionysius, a mere being, could really know and say that God is unknowable and unsayable, having attained to a hyper-being perspective from which such things are knowable and sayable. (Dionysius could also therefore know and say that humans can attain to such a state).

Importantly, this solution is reinforced by passages elsewhere in the corpus that show that Dionysius knows quite a lot about the character of silent unknowing knowing. The opening sentences of the Divine Names maintains "we are unspeakably and unknowingly conjoined to unspeakable things and unknowable things through a union that is superior to our rational and intellectual power and activity" ( $D N 1.1,585 \mathrm{~B}-588 \mathrm{~A})$. The first Epistle confirms this, adding that our knowledge of that which is hyper everything known is hyper-nous knowledge (which escapes those with knowledge of being):

But God, hyper-established hyper mind and being, not known and not being in general, is hyper-beingly and is known hyper-mind. And the surpassingly complete unknowing is a knowledge of that which is hyper everything known $(E P 1,1065 \mathrm{AB})$.

The fourth Epistle adds that those "who see divinely will know hyper mind that the affirmations about Jesus' love for humanity have the power of preeminent negation (ن் (EP 4, 1072BC). Divine Names 7.3 also identifies unknowing knowing as hyper-nous knowledge, going on to specify that nous is illumined by the inscrutable depth of wisdom when it stands away from all beings and itself:

And there is, further, the most divine knowledge of God, which is known through unknowing during the union hyper mind, when the mind, having stood apart from all beings, then having given up even itself, is united to the hyper-brilliant rays, there illumined by the inscrutable depth of wisdom $(D N 7.3,872 \mathrm{AB})$.

And given this standing away, Divine Names 7.4 exclaims that what is in fact complete knowledge appears as madness from the perspective of ordinary speech and intellect ( $D N 7.4,872 \mathrm{D})$.

Moreover, what we see in all these passages is not only a characterization of the state of silent unknowing knowing (as hyper-nous knowing) but also an indication of how this state is achieved: one must stand away from all beings and one's mind; one must remove all beings, from last to first; and one must leave behind all sensible and intelligible things. This is the path of aphairetic removal, best exemplified in the hymns of Mystical Theology 4 and 5, which qua hymns most likely served a performative-ritualistic role within the liturgy. ${ }^{37}$ The assertive illocutionary acts (removals) of Mystical Theology 4 and 5 are therefore best understood as declarative-assertives assertive illocutionary acts that by virtue of their proper performance convey the utterer to a state of silent unknowing knowing. ${ }^{38}$ Thus, while ineffability directions culminate ineffability assertions, serving to direct to a state of ineffability rather than simply asserting ineffability, these ineffability declarative-assertives culminate ineffability directions, actually producing a state of silent unknowing knowing. That which seems to be a simple series of assertions about God's (relative) ineffability is actually a performative means of creating a state of ineffability in the asserter, of conveying the hymnist or liturgist to a hyper-ousia plane from which God's ineffability and unknowability to beings can be known hyper-nous.

It is crucial then to bear in mind that the aphairetic removals of Mystical Theology 4-5 do more than simply remove from God; they also state preeminence. The Dionysian God is more than just ineffable and unknowable - the Dionysian God is hyper effable and hyper knowable. The 
following rule of illocutionary force therefore regulates Dionysius' assertions about God in a manner comparable to the way in which Dionysius' rules of reference and predication regulate Dionysius' naming of God:

- Dionysian Rule of Assertion: God is properly asserted as that which, on the one hand, is ineffable (or beyond the category of in/effability) and unknowable (or beyond the category of un/knowability) from the perspective of being, and on the other hand, preeminently effable (or sayable hyper-logos) and preeminently knowable (or knowable hyper-nous) from the perspective of hyper-being as the hyper-being cause of all.

This rule, in conjunction with the above rules of reference and predication, constitute an intratextual logic or grammar, regulating Pseudo-Dionysius' otherwise antinomian techniques of illocution. The Dionysian corpus is rule-governed at the illocutionary level; the Dionysian God is not therefore absolutely ineffable.

\section{Expressions of Inexpressibility above the Speech Act}

In this third section of the paper things go a bit differently. The overall goal is that of identifying and analyzing Dionysian expressions of inexpressibility above the speech act. But such identification is focused on Dionysian metaphors of ineffability - metaphors of darkness and metaphors of height - since these metaphors have an internal structure and external interconnection that extends beyond any one speech act. And such analysis is prosecuted by means of the metaphor theory of George Lakoff and Mark Johnson - in particular their notions of gestalt and entailment since Searle does not offer tools for the analysis of systematically structured and interconnected metaphors. Nevertheless, this section of the paper draws a conclusion similar to those of the previous sections: Dionysian metaphors of ineffability are rule-governed; the Dionysian God is not completely ineffable.

As in the case of Searle's theories of reference and predication, Searle's theory of metaphor is quite elementary: metaphors are cases in which speaker's utterance meaning differs from literal word or sentence meaning; the interpretation of metaphors therefore requires only principles of conversation and rules of speech act theory, the following three of which Searle enumerates:

1. If the utterance is defective if taken literally, look for an utterance meaning that differs from sentence meaning.

2. Whenever you hear "S is P", to find possible values of R [utterance meaning] look for ways in which $\mathrm{S}$ [subject expression] might be like $\mathrm{P}$ [literal sentence meaning], and to fill in the respect in which $\mathrm{S}$ might be like $\mathrm{P}$, look for salient, well known, and distinctive features of $P$ things.

3. Go back to the $\mathrm{S}$ term and see which of the many candidates for the values of $\mathrm{R}$ are likely or even possible properties of $S^{39}[23$, pp. 105-106].

But here, unlike Searle's theories of reference and predication, simplicity is a vice. To pin metaphorical meaning solely on deviant usage is to fail to appreciate those aspects of signs and sign-systems that make possible metaphorical usage: the richly connotative and deeply embodied nature of signs as well as the systematically structured and intricately interconnected nature of signsystems. And to limit the interpretation of metaphors to the above principles of conversation and rules of speech act theory is to fail to provide concrete tools for the analysis of systematically structured and interrelated metaphors. This section of the paper therefore turns to the metaphor theory of George Lakoff and Mark Johnson, which, despite an overreaching theory of metaphor and uncharitable reading of its opponents, provides such tools. ${ }^{40}$

Lakoff and Johnson make two crucial insights about the embodiment and structure of abstract concepts: humans draw on concrete bodily experience in understanding and expressing abstract concepts, and they do so by systematically structuring abstract concepts in accordance with 
bodily experiences. Particularly relevant to the former insight is Lakoff and Johnson's idea of a primary metaphor. While all metaphors are "cross-domain mappings" from source domains to target domains, the primary metaphor maps sensorimotor source domains (vehicles) to subjective target domains (tenors), and does so both naturally and unconsciously. ${ }^{41}$ This mapping is the result of two processes: an initial conflation of sensorimotor experiences like warmth and subjective judgments like affection such that neural activations of the sensorimotor source network are immediately "projected" to the subjective target network, and a later awareness of and differentiation between these experiences such that sensorimotor concepts can be used to conceptualize and verbalize subjective experiences in absence of their corresponding sensorimotor experiences. These primary metaphors then function as atoms for the molecular complex metaphor, which, although not directly grounded in a single sensorimotor experience, receives an indirect grounding through its component primary metaphors. ${ }^{42}$ Thus, Lakoff and Johnson believe that "[m]any, if not all, of our abstract concepts are defined in significant part by conceptual metaphor" ${ }^{\prime 3}[15$, p. 128].

Even more importantly for the analysis of Dionysian metaphors, Lakoff and Johnson understand abstract concepts to be internally structured and interconnected. This is due to what they call gestalt and entailment. The former notion, gestalt, refers to the way in which abstract concepts are internally structured into coherent wholes by carrying over the inferential patterns of the source domain into the target domain. Just as some concept itself is understood in terms of some metaphor, so that concept's component parts - e.g., participants, parts, stages, linear sequences, purposes, and causes - are understood in terms of that metaphor's component parts. ${ }^{44}$ Thus, if, for example, argument is metaphorized as war, then its participants are metaphorized as adversaries; its parts, as attack and defense; its purpose, as victory. In this way metaphors bestow a complex internal structure upon concepts that reaches far beyond the actual source-target mapping itself. Quite commonly, though, concepts are structured by multiple, apparently inconsistent metaphors. ${ }^{45}$ In such cases, these different metaphors will cohere to the degree to which they possess overlapping experiential entailments. The apparently inconsistent metaphors an argument is a container and an argument is a journey, for example, cohere due to the following overlapping entailments: as one makes an argument, more surface is created; as more surface is created, more ground is covered; as more ground is covered, more content is provided ([14], pp. 93-94). Thus the notion of entailment provides a means of showing how partially inconsistent metaphors to "fit together," even though there is no single image that completely fits them ([14], p. 94). ${ }^{46}$ Together these tools are invaluable to the analysis of Dionysian metaphors of ineffability: the notion of gestalt serves as a means of elucidating the internal complexity of such metaphors, while entailment offers a way of reconciling apparent inconsistencies within and between these metaphors by demonstrating their overlapping entailments. $^{47}$

The most common way in which Dionysius metaphorizes divine ineffability and unknowability is by using darkness to symbolize the dwelling place of God. The Mystical Theology is rife with such metaphors. Alluding to Psalms 18:22, Mystical Theology 1.2 asserts that darkness is the hiding place of God (MT 1.2, 1000A). Mystical Theology 1.3 follows this not only by citing Bartholomew as authority for the claim that the good cause of all is undisguisedly and truly manifested to those who enter "into the darkness where, as the scriptures say, the beyond all truly is," but also by illustrating this claim with the example of Moses, who, after being released from what sees and is seen, "enters into the truly mystical darkness of unknowing" where he is "united surpassingly to the completely unknown" (MT 1.3, 1000C, 1001A). And then Mystical Theology 2 maintains that the removal of everything yields a seeing of "this hyper-being darkness that is hidden by all the light among beings" (MT 2, 1025B). These passages draw on the metaphor unknowing is darkness, an extension of the primary metaphor knowing is seeing, to symbolize the ineffability and unknowability of God as a dwelling in darkness. [15, pp. 53-54, Cf., 8, p. 296] Thus this metaphor - in conjunction with the primary metaphors states are locations, destinations are purposes, and 
means are paths $[15$, pp. 52-53. Cf., 8, p. 286] - provides a gestalt that structures the complex Dionysian metaphor God dwells in darkness (into which the seeker of God must enter) as follows:

Table 2: Gestalt of the Dionysian Metaphor God Dwells in Darkness

\begin{tabular}{|l|l|}
\hline Participants & $\begin{array}{l}\text { Christian as seeker, God as that which is being } \\
\text { sought }\end{array}$ \\
\hline Parts & $\begin{array}{l}\text { Lighted area in which God does not dwell; dark area } \\
\text { in which God does dwell }\end{array}$ \\
\hline Stages & First seeking for God, then finding God \\
\hline Linear Sequences & Progressive entry into the divine darkness \\
\hline Purposes & Finding God by entering into the divine darkness \\
\hline Causes & $\begin{array}{l}\text { Seeker enters into the divine darkness by removing } \\
\text { the things of being from God }\end{array}$ \\
\hline
\end{tabular}

This metaphor gets much of its force from the fact that it draws on the primary metaphor knowing is seeing: since knowledge is (near) universally metaphorized as seeing and sight requires light, darkness is indeed an apt symbol for ignorance. But this metaphor is also apt due to the fact that it highlights an important difference between the metaphorical darkness that hides God and the physical darkness that obscures physical objects: God is not a corporeal object that could be enshrouded in actual darkness. ${ }^{48}$

But there is a tension in this metaphor: on the one hand, God dwells in darkness and is therefore unknowable; on the other hand, the Christian seeker enters into this darkness in order to find God - to be "united surpassingly to the completely unknown by an inactivity of all knowledge," to "unhiddenly know this unknowing that is covered by all the knowledge among all beings," to "see this hyper-being darkness that is hidden by all the light among beings." To put this tension in terms of Lakoff and Johnson's metaphor theory, there is an apparent incompatibility between the primary metaphor knowing is seeing, which entails that God cannot be known if God cannot be seen, and a cluster of proximity metaphors - similarity is proximity, intimacy is proximity, knowing is proximity, degree is distance along a path ${ }^{49}$ - which entail that, as the seeker draws close to God, the seeker better knows God. Here we have what initially appears to be an antinomian grammatical technique. One possible way of resolving it is to say that, upon entering into the divine darkness, what the seeker knows about God is that God is unknowable. But this does not do justice to fact that Dionysius describes the divine darkness not as a simple or stark darkness, but as a luminous or hyper-light darkness. (And it also does not do justice to the fact that the experience of luminous darkness is a hyper-nous knowing). On a number of occasions Dionysius very clearly declares that darkness should not be understood as a privation of light. Darkness, rather, is a preeminence of light. Epistle 5, for example, identifies divine darkness with unapproachable light and hyper-having brightness:

The divine darkness ( $\gamma$ vóфos) is the "unapproachable light" in which it is said God lives,

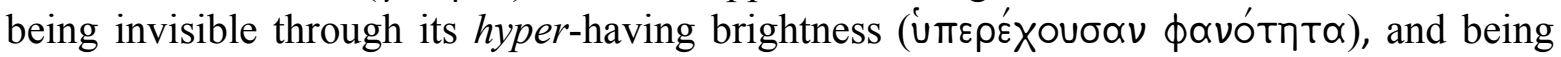

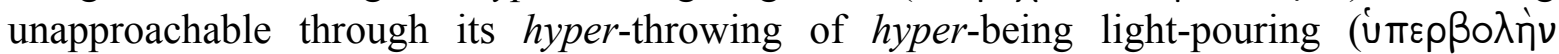

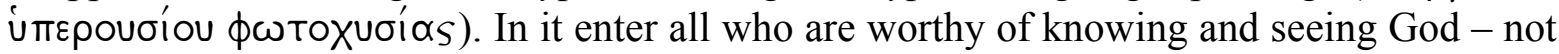
(actually) knowing and seeing God, but truly coming to be in the hyper sight and knowledge, knowing this thing, that it is after all perceptible and intelligible things, and saying prophetically, "Knowledge of you is too wonderful for me; it is too high; I cannot attain it." Thus it is said that the divine Paul knew God as hyper all intelligence and knowledge. Hence, he says that his ways are inscrutable and "his judgments are 
unsearchable," and his gifts are indescribable, and his peace transcends "all understanding," for he found him who is hyper all and knew beyond understanding that he is beyond all as the cause of all (EP 5, 1073A-1076A).

And Mystical Theology 1.1 not only petitions Trinity to guide Christians to the highest summit of mystical logiōn that is both hyper-unknown and hyper-brilliant but also implores Timothy to be uplifted to the hyper-being rays of the divine darkness:

Trinity hyper-being and hyper-god and hyper-good, overseer of Christians in divine

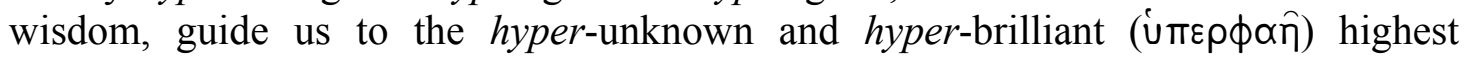
summit of mystical logion; there the simple, absolute, and unchanged mysteries of

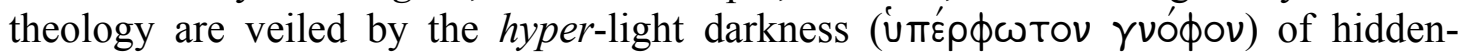
mystical silence, hyper-illuminating the hyper-lightest in the darkest ('Ev $\tau \omega$

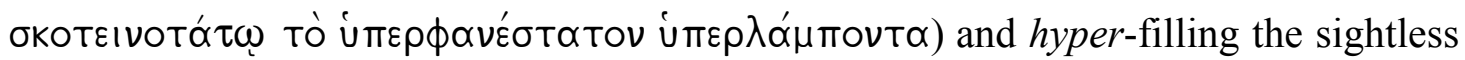
minds with hyper-beautiful beauties in the wholly imperceptible and invisible.

This is my prayer; and you, dear Timothy, in the earnest study of mystical sights, leave behind sensible and intellectual activities, all sensible and intelligible things, all non-beings and beings, and unknowingly strive upward, as far as possible, toward the unity of that which is hyper all being and knowledge. By an undivided and absolute ecstasis of yourself and everything, shedding all and freed from all, you will be purely

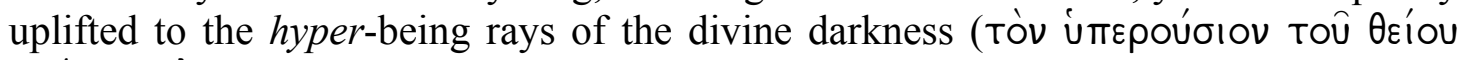
бкótous ákтiva) (MT 1.1, 997A-1000A).

And Mystical Theology 2 offers a prayer to come to the hyper-light darkness:

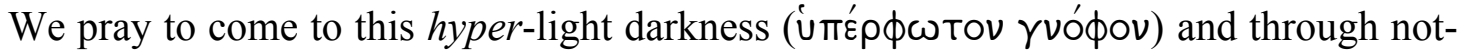
seeing and not-knowing to see and to know not to see and to know that which is hyper sight and knowledge itself - for this is truly seeing and knowing $(M T 2,1025 \mathrm{~A})$.

Given the above claim that divine darkness is an unapproachable light, these hyper-light constructions cannot be read simply as indications that divine darkness is symbolically beyond light. Divine darkness must in some sense also be excessive light. But then both darkness and light would symbolize unknowing.

Another way of attempting to resolve these conflicts, more particularly of explaining the assertion that God dwells in luminous darkness, is to interpret them as paradox. Here, Dionysius could be understood as conveying the super-unknowability of God through the paradoxical conjunction of two conflicting extensions of the basic metaphor knowing is seeing: unknowing is excessive darkness, and unknowing is blinding light. (The paradox would be generated by the fact that although both excessive darkness and excessive light prevent seeing, these two states cannot obtain at one and the same time). Here, the Dionysian God would be so unknowable that it dwells in inscrutable darkness and blinding light at one and the same time. But this "solution" fails to take account of Dionysius' claim that true knowledge of God is revealed in such states of luminous darkness, that proximity to God yields "knowledge" of God. A more plausible solution instead takes luminous darkness to be a symbol for hyper-mind knowledge of the hyper-being God - a transcendent form of knowledge that requires ignorance of the things of being. Thus, whereas simple light stands for knowledge of the things of being and simple darkness signifies ignorance with respect to the things of being, luminous darkness symbolizes both the complete absence of knowledge from the perspective of being and a hyper-mind knowledge of the hyper-being God. The key to understanding Dionysius' use of metaphors of light and darkness lies therefore in a proper understanding these metaphors' inner complexity. Here, Lakoff and Johnson's notion of gestalt is 
again of considerable use, as it shows us precisely where this complexity resides, allowing us to emend our former gestalt as follows:

Table 3: Gestalt of the Dionysian Metaphor Knowledge of God is Luminous Darkness

\begin{tabular}{|l|l|}
\hline Participants & $\begin{array}{l}\text { Christian as seeker, God as that which is being } \\
\text { sought }\end{array}$ \\
\hline Parts & $\begin{array}{l}\text { Lighted area in which God does not dwell, } \\
\text { luminously dark area in which God does dwell }\end{array}$ \\
\hline Stages & $\begin{array}{l}\text { First seeking for God by entering into the divine } \\
\text { darkness by removing the (lighted) things of being, } \\
\text { then finding God by having the darkness illuminated } \\
\text { by God }\end{array}$ \\
\hline Linear Sequences & Progressive entry into the divine luminous darkness \\
\hline Purposes & $\begin{array}{l}\text { Finding God in the divine luminous darkness by } \\
\text { attaining hyper-nous knowledge of God }\end{array}$ \\
\hline Causes & $\begin{array}{l}\text { Seeker enters into the divine darkness by removing } \\
\text { the things of being from God, God illuminates the } \\
\text { darkness by bestowing hyper-nous knowledge of the } \\
\text { divine hyper-being }\end{array}$ \\
\hline
\end{tabular}

Like the basic metaphor knowing is seeing, the Dionysian metaphor divine knowledge is luminous darkness possesses two stages: a stage of initial darkness or ignorance, and a state of final illumination or knowledge. But unlike the basic metaphor knowing is seeing, the Dionysian metaphor divine knowledge is luminous darkness does not present these stages as mutually exclusive. To enter into the light of hyper-mind knowing is to remain within the darkness of ignorance of the things of being. To enter into the divine darkness is to be illuminated. The power of this Dionysian metaphor is its ability to do double duty, conveying both states at once.

A second metaphor of divine ineffability, height, is not as common as that of darkness and, moreover, never occurs independently of it. Nevertheless, height is a crucial metaphor for understanding the nature of God in the Dionysian corpus, especially since procession is symbolized as movement down from God, reversion, as movement up to God. But this God that is "up" is metaphorized in two seemingly conflicting ways: both as unknown and as more. As many of the above passages illustrate, the primary metaphor unknowing is up is frequently in play in the Mystical Theology where it is conjoined with the metaphor unknowing is darkness. The opening prayer of the first chapter asks God to guide Christians to "the hyper-unknown and hyper-brilliant

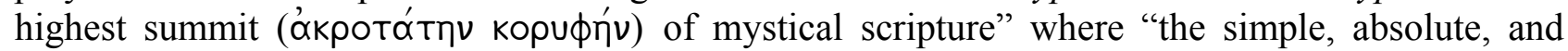
unchanged mysteries of theology are veiled by the hyper-light darkness of hidden silence" (MT 1.1, 997AB). Not much later, the first chapter adduces Bartholomew's belief that God is manifested

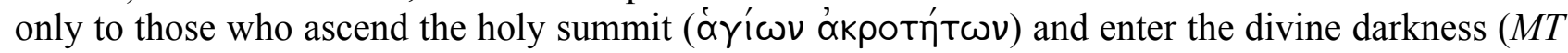
$1.3,1000 \mathrm{C})$. And then the first chapter draws to a close by reporting Moses as one who has in fact made such an ascent and entered "the truly mystical darkness of unknowing" (MT 1.3, 1000D1001A). In these passages Dionysius implicitly draws on the basic metaphor unknowing is up, which, according to Lakoff and Johnson, has its experiential basis in the fact that it is easier to see and grasp objects that are close to the ground, and is therefore closely related to the operative metaphor in Dionysius' use of darkness as a symbol of divine unknowability, knowing is seeing. ${ }^{50}$ [15, p. 54] These two metaphors reinforce one another, serving to symbolize God as doubly unknowable (according to the things of being) - unknowable as dwelling not only in impenetrable darkness but also on an inaccessible mountain peak; unknowable, in short, as residing on an 
enshrouded summit. The gestalt for this metaphor - God dwells on an enshrouded summit (up to which the seeker must ascend) - can be tabulated as follows:

Table 4: Gestalt of the Dionysian Metaphor God Dwells on an Enshrouded Summit

\begin{tabular}{|l|l|}
\hline Participants & $\begin{array}{l}\text { Christian as seeker, God as that which is being } \\
\text { sought }\end{array}$ \\
\hline Parts & $\begin{array}{l}\text { Base of mountain where God does not dwell, } \\
\text { enshrouded summit where God dwells }\end{array}$ \\
\hline Stages & First seeking, then finding \\
\hline Linear Sequences & Progressive climbing up the divine mountain \\
\hline Purposes & Finding God by reaching the enshrouded summit \\
\hline Causes & $\begin{array}{l}\text { Seeker reaches the enshrouded summit by removing } \\
\text { the things of being from God }\end{array}$ \\
\hline
\end{tabular}

As in the case of God dwells in darkness, two things are of note here. This metaphor gets much of its force from the fact that it draws on the primary metaphor unknowing is up: since knowledge is (near) universally metaphorized as grasping objects that are close at hand and objects that are up high are not close at hand, height is indeed an apt symbol for ignorance. And this metaphor is also apt due to the fact that it highlights an important difference between the metaphorical height that distances God and physical height that distances physical objects: God is not a corporeal object that could be physically distanced from humans.

There is of course the aforementioned tension at the heart of this metaphor's gestalt: on the one hand, God dwells on an enshrouded summit and is therefore unknowable; on the other hand, the Christian seeker climbs to this divine summit in order to find God. In terms of Lakoff and Johnson's metaphor theory, this is again to say that there is an apparent tension between, in this case, the primary metaphor unknowing is up, which entails that God cannot be known if God resides on a mountain summit, and the aforementioned cluster of proximity metaphors, which entail that as the seeker ascends the divine mountain, she draws closer to God thereby better knowing God. But in this case this proximity metaphor cluster is most evident in passages that speak of the removal of divine names from God as an ascent from last things that are least similar to God (in this case perceptible symbols) to first things that are more similar to God (in this case divine names). Mystical Theology 2 tells us that whereas the method of thesis begins from the first things and descends through the middle things to the last things, the method of aphairesis ascends from the last thing to the first things in a search for the highest principles (MT 2, 1025B). And Mystical Theology 3 uses similar language, adding an example that makes it clear that the first things (e.g., life and goodness, speaking and thinking) are more similar to God, while the last things (e.g., air and stone, drunkenness and anger) are further away from God:

But why, you may ask, do we begin the divine removal from the last things

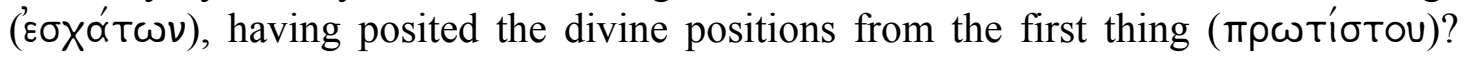
[The reason is] that [when] positing that which is hyper all position it is necessary to

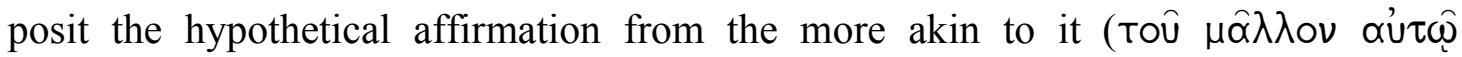

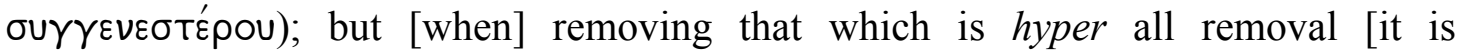
necessary] to remove from the farthest away from it ( $\tau \hat{\omega} \nu \mu \hat{\alpha} \lambda \lambda$ ov $\alpha \hat{u}$ Toû

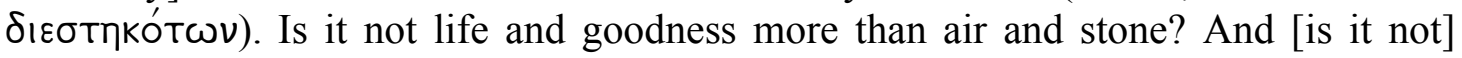
more not drunkenness and not anger than not speaking and not thinking? (MT 3, 1033CD). 
In these passages up signifies not (only) God's ineffability and unknowability but (also) divine names that are more and more similar to God. As one climbs the divine mountain, one removes divine names that are more and more similar, thereby getting closer to closer to God. But this would seem to make no sense! If these divine names are more and more accurate, how can the removal of them from God bring us closer and closer to God? Is this again an antinomian grammatical technique, the clashing of two different logics of transcendence?

Of course, we have already seen how this apparent inconsistency is resolved in the case of divine names: the God that is not- $d n$ from the perspective of being is more-dn-than-most- $d n$ from the perspective of hyper-being (qua precontaining both the divine names themselves and the properties they source in a manner that is hyper-unified and hyper-existent). The removal of divine names from God reveals their preeminence, thereby drawing us closer and closer to the hyper-being God. The ascent to God is therefore at one and the same time an ascent into darkness with respect to the things of being and an illumination of the hyper-being God. What remains to be shown, however, is how these contrasting uses of height are resolved at the metaphorical level. Here, it is crucial to see that height is a metaphor that serves to symbolize not only divine unknowability but also divine preeminence. In the above passages from Mystical Theology Dionysius draws the primary metaphor more is up, which has its experiential basis in "the observation of rising and falling levels of piles and fluids as more is added or subtracted" (as well as the primary metaphor good is up, which assigns a positive valence to such rising piles and fluids). ${ }^{51}[15, \mathrm{p}$. 51] Now, it would seem that this is in contradiction with the primary metaphor unknowing is up. ${ }^{52}$ One and the same thing cannot be both unknowably removed and preeminently superabundant. But, as has been shown in the preceding chapters, this is just what the Dionysian corpus says. And here it is the metaphor of height that gives semantic expression to this theological claim, doing double duty by signifying not only God's utter unknowability (according to the things of being) but also God's preeminent superabundance. Thus, we can emend our earlier gestalt as follows:

Table 5: Gestalt of the Dionysian Metaphor God is Up and More

\begin{tabular}{|l|l|}
\hline Participants & $\begin{array}{l}\text { Christian as seeker, God as that which is being } \\
\text { sought }\end{array}$ \\
\hline Parts & $\begin{array}{l}\text { Base of mountain where God does not dwell, } \\
\text { enshrouded summit where God does dwell }\end{array}$ \\
\hline Stages & $\begin{array}{l}\text { First seeking for God by climbing up the mountain } \\
\text { by removing the things of being, then finding God } \\
\text { on the mountain as that which is hyperbeingly } \\
\text { preeminent }\end{array}$ \\
\hline Linear Sequences & Progressive climbing up the divine mountain \\
\hline Purposes & $\begin{array}{l}\text { Finding God by climbing to the enshrouded summit } \\
\text { where God is revealed as hyperbeingly preeminent }\end{array}$ \\
\hline Causes & $\begin{array}{l}\text { Seeker reaches the enshrouded summit by removing } \\
\text { the things of being from God, after which God is } \\
\text { revealed as hyperbeingly preeminent }\end{array}$ \\
\hline
\end{tabular}

Here, two things should be mentioned. Firstly, Dionysian metaphors of height more or less coincide with Dionysian metaphors of light: on the one hand, the metaphors unknowing is up and unknowing is darkness symbolize God as unknowable according to the things of being; on the other hand, the metaphors more is up and knowing is light symbolize God as hyper-nous knowable in hyper-being preeminence. Secondly, it is the enshrouded divine mountain, Dionysius' favorite example of both height and light, that serves as a common entailment between these otherwise 
conflicting metaphors: mountain peaks make outstanding examples of the unknown, especially when they are enshrouded in dark clouds that obscure vision of them from the bottom; in ascending a mountain one ascends over more and more of the mountain, thereby getting closer and closer to the "unknown" summit; but upon reaching the summit, one sometimes finds it penetrated by the light of the sun.

There is therefore a logic or rule to Dionysius' application of metaphors to God. Such metaphors must be able to do double duty, conveying not only the ineffability and unknowability of God with respect to the things of being but also the hyper-nous knowing of the hyper-ousia God that is the cause of all things of being.

- Dionysian Metaphor Rule: God is properly metaphorized as that which is both ineffable and unknowable from the perspective of being and preeminently effable and knowable from the perspective of hyper-being.

As in the cases of reference, predication, and illocution, this rule constitutes an intra-textual logic or grammar, regulating Pseudo-Dionysius' otherwise antinomian techniques of symbolization. This rule therefore shows that the Dionysian God is not absolutely ineffable.

But the symbol of the divine mountain serves as more than just a harmonizing entailment of Dionysian metaphors of height and light; it generates a story of ascent that offers a "narrative isotopy" for the entire Dionysian corpus. ${ }^{53}$ As the Christian climber ascends the divine mountain, removing more and more things of being from God, she progressively enters into the unknowing darkness - a state in which nothing of being can be said or known about God. But upon arrival at the summit of the enshrouded divine mountain, the Christian climber "knows" God hyper-nous as the hyper-ousia cause of all things, a cause that precontains its effects in a manner that is hyperexistent and hyper-unified. This is the narrative isotopy of the Dionysian corpus, a single story that makes possible a uniform reading of the corpus, reconciling not only these metaphors of darkness and height but also the other grammatical techniques considered above: hyper-names, negation, ineffability assertion, and ineffability direction. This isotopy constitutes a textual narrative, regulating all of Dionysius' techniques of ineffability. This isotopy therefore shows that the Dionysian God is not absolutely ineffable.

\section{References}

1. de Andia, Ysabel. Henosis: L'Union à Dieu chez Denys l'Aréopagite. New York: E.J. Brill, 1996.

2. Aristotle. The Complete Works of Aristotle: The Revised Oxford Translation, 2 vols. Ed. Jonathan Barnes. Princeton: Princeton University Press, 1984.

3. Carabine, Deirdre. The Unknown God: Negative Theology in the Platonic Tradition: Plato to Eriugena. Louvain: W.B. Eerdmans, 1975.

4. Corbin, Michel. "Négation et Transcendance dans l'Euvre de Denys." Revue Des Sciences Philosophiques et Théologiques 69 (1985): 41-76.

5. Eco, Umberto. A Theory of Semiotics. Bloomington: Indiana University Press, 1976.

6. Eco, Umberto. Semiotics and the Philosophy of Language. Bloomington: Indiana University Press, 1984.

7. Golitizin, Alexander. "Suddenly Christ: The Place of Negative Theology in the Mystagogy of Dionysius Areopagites." In Mystics: Presence and Aporia, eds. Michael Kessler and Christian Sheppard, 8-37. Chicago: University of Chicago Press, 2003.

8. Grady, Joseph. Foundations of Meaning: Primary Metaphors and Primary Scenes. Ann Arbor: UMI Dissertation Services, 1997.

9. Henle, Paul. "Mysticism and Semantics." Philosophy and Phenomenological Research 9 (1949): 116-122.

10. Horn, Laurence R. A Natural History of Negation. Palo Alto, CA: CSLI Publications, 2001. 
11. Jones, John D. "Introduction." In The Divine Names and Mystical Theology. Milwaukee: Marquette University Press, 1980.

12. Knepper, Timothy. "Not Not: The Method and Logic of Negation in the Dionysian Corpus," American Catholic Philosophical Quarterly 82 (2008): 619-637.

13. Knepper, Timothy. "Ranks Are Not Bypassed; Rituals Are Not Negated." Modern Theology. forthcoming.

14. Lakoff, George, and Mark Johnson. Metaphors We Live By. Chicago: The University of Chicago Press, 1980.

15. Lakoff, George, and Mark Johnson. Philosophy in the Flesh: The Embodied Mind and its Challenge to Western Thought. New York: Basic Books, 1999.

16. Liddell, George, and Robert Scott. A Greek-English Lexicon, revised edition of new (ninth) edition. Oxford: The Clarendon Press, 1968.

17. Plato. Complete Works, ed. John M. Cooper. Indianapolis: Hackett Publishing Company, 1997.

18. Proudfoot, Wayne. Religious Experience. New York: University of California Press, 1985.

19. Pseudo-Dionysius. Corpus Dionysiacum I: De Divinis Nominibus. Ed. Beate Regina Suchla. New York: Walter de Gruyter, 1990.

20. Pseudo-Dionysius. Corpus Dionysiacum II: De Coelesti Hierarchia, de Ecclesiastic Hierarchia, de Mystica Theologia, Epistulae. Eds. Günter Heil and Adolf Martin Ritter. New York: Walter de Gruyter, 1991.

21. Pseudo-Dionysius: The Complete Works. Translated by Colm Luibheid. Mahwah, New York: Paulist Press, 1987.

22. Rist, J.M. "Mysticism and Transcendence in Later Neoplatonism." Hermes 92 (1964): 213225.

23. Searle, John. Expression and Meaning: Studies in the Theory of Speech Acts. New York: Cambridge University Press, 1979.

24. Searle, John. Intentionality: An Essay in the Philosophy of Mind. New York: Cambridge University Press, 1983.

25. Searle, John. Speech Acts: An Essay in the Philosophy of Language. New York: Cambridge University Press, 1969.

26. Searle, John, and Daniel Vanderveken. Foundations of Illocutionary Logic. New York: Cambridge University Press, 1985.

27. Van den Berg, R. M. Proclus' Hymns: Essays, Translations, Commentaries. Boston: Brill, 2001.

28. Vanneste, Jan. Le mystère de dieu: Essai sur la structure rationnelle de la doctrine mystique du pseudo-Denys l'Aréopagite. Brussels: Desclée de Brouwer, 1959.

\section{Notes}

1. The Dionysian corpus is composed of four treatises - Celestial Hierarchy $(\mathrm{CH})$, Ecclesiastical Hierarchy $(E H)$, Divine Names $(D N)$, and Mystical Theology $(M T)$ - and ten epistles (EP). Although its author claimed to be the first-century Dionysius whom the book of Acts reports converting to Christianity after hearing the apostle Paul's sermon about the unknown God at the Areopagus in Athens (Acts 17:34), contemporary scholarship has definitely dated this unknown author's work to the early-sixth century and conclusively established its dependence on both late Neoplatonic and Patristic texts and motifs. Due to the literal inaccuracy of Colm Luibheid's Paulist Press translation of the Dionysian corpus, I have translated all quoted passages from the Dionysian corpus directly from the critical edition of the Dionysian corpus. See [21], [19], [20].

2. Absolute ineffability applies to that about which nothing can be said (except, perhaps, that it is ineffable). As soon as that something gets identified or predicated or asserted or metaphorized as a certain something (e.g., a hyper-being cause) or as doing a certain something (e.g., causing all things), it ceases to be absolutely ineffable. To provide the rules that govern such identifying or predicating or asserting or metaphorizing is 
therefore to show how that which is so identified or predicated or asserted or metaphorized is not absolutely ineffable.

3. Although an account of singular definite referring expressions is avowedly "incomplete," Searle believes it constitutes a necessary point of origin for other kinds of referring expressions (p. 72).

4. If I had the space here, I would side with Searle against his causal-theory opponents: not only do the causal critiques of descriptivism fail to hit their mark, but the causal theory of reference in fact depends upon and therefore is a type of descriptive theory of reference. But this hardly matters for the sake of an analysis of referring expressions in texts since such an analysis can only proceed by way of the analysis of identifying descriptions. Put differently, textual identifying descriptions are linguistic-empirical phenomena that may be identified and analyzed using concrete tools, whereas casual "connection" is not (unless it is rendered in terms of possession and provision of identifying descriptions, which is to confirm Searle's claim that the causalhistorical theory of reference is just a variant form of the descriptive theory of reference. See [24], pp. 244246.

5. A quick preliminary issue is first in order: since every identifying description serves not only to pick out a referent but also to raise the question of the truth of itself of the referent, and since every predication serves not only to raise the question of the truth of itself of the referent but also to pick out the referent, referential and predicative techniques will be considered at one and the same time.

6. A Thesaurus Linguae Graecae search reveals 728 total occurrences of hyper in the Dionysian corpus, 559 of which are hyper-prefixed terms. Much less frequent are the preposition epekeina (22 occurrences) and the comparative kreitton (22 occurrences).

7. Very similarly, the spatial direction of up has two different metaphorical applications in everyday discourse, as it is used to convey both a sense of more and a sense of unknown. According to Lakoff and Johnson, these two metaphors - more is up and unknown is up - have very different experiential bases: the former, that of observing rising and falling levels of piles and fluids; the latter, that of finding it easier to grasp something and look at it if it is on the ground. See [14], p. 21; [15], pp. 51, 54. For Dionysius' use of height as a metaphor for divine transcendence, see section III below.

8. I've gone with some of the more standard translations of hyperbolē (excess), hyperexō (preeimence), and hyperairō (exceeding) here. But note that if the hyper prefix is retained on each of these terms, they translate, respectively, more like hyper-throwing, hyper-having, and hyper-raising.

9. See, for example, [4].

10. In translating from the Dionysian corpus, I translate aphairesis as removal and apophasis as negation, as seems to be common translational practice outside of Dionysian studies. (Note that the Paulist Press translation translates aphairesis as denial; this, however, does not properly preserve the semantic distinction between aphairesis and apophasis.) But in my own prose I leave the Greek term apophasis un-translated so that the English term negation can function inclusively of both apophasis and aphairesis. For stylistic ease, I also sometimes translate aphairesis as removal in my own prose.

11. The register of Greek terms in the critical edition of the Dionysian corpus lists twenty-six occurrences of

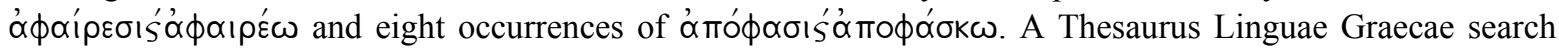

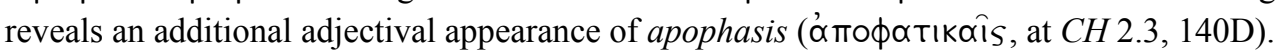

12. According to Aristotle, both infinite or indefinite names (e.g., not-wise) and alpha privatives (e.g., wise-less or un-wise) are instances of predicate-term negation. See Aristotle's Categories 11b17ff, 11b38ff, 13b12ff; On Interpretation 19b20ff, 20a31ff; and Prior Analytics 51b5ff. See also [10], pp. 6-21, 102-103, 110.

13. Note that it is the individual who sees divinely hyper-mind who knows this. More will be said about such hyper-nous knowing in the next two sections.

14. See my paper "Not Not" for the claims that (1) aphairesis is properly contrasted with thesis as the difference between a method that removes properties from God and a method that posits properties of God, and (2a) apophasis is properly contrasted syntactically with kataphasis as the difference between a negative predicateterm and a positive predicate-term, and (2b) semantically with sterēsis as the difference between a negative predicate-term that signifies excess and a negative predicate-term that signifies lack [12]. This is how I render these distinctions in tabular form: 


\begin{tabular}{|c|c|c|}
\hline & Method & Logic \\
\hline Positive & $\begin{array}{l}\text { Thesis: the position of a positive } \\
\text { (kataphatic) predicate-term of God (e.g., } \\
\text { God is wise) }\end{array}$ & $\begin{array}{l}\text { Kataphasis: a positive predicate-term (e.g., } \\
\text { wise) }\end{array}$ \\
\hline \multirow[t]{2}{*}{ Negative } & \multirow{2}{*}{$\begin{array}{l}\text { Aphairesis: the removal of a negative } \\
\text { (apophatic) predicate-term from God (e.g., } \\
\text { God is not-wise) }\end{array}$} & $\begin{array}{l}\text { Apophasis: a negative predicate-term of } \\
\text { excess (e.g., not-wise qua hyper wise) }\end{array}$ \\
\hline & & $\begin{array}{l}\text { Sterēsis: a negative predicate-term of lack } \\
\text { (e.g., not-wise qua lacking wisdom) }\end{array}$ \\
\hline
\end{tabular}

15. $M T 2,1025 \mathrm{AB}$. Here are two other pieces of evidence in support of my claim that aphairetic removal discloses divine preeminence. First, Dionysius' discussion of the two ways of approaching God at Divine Names 7.3 combines aphairesis and hyperoche in one and the same way (contrasting it to the way of causation):

It is never true to say that we know God in its nature since this is unknown and hyper-raised

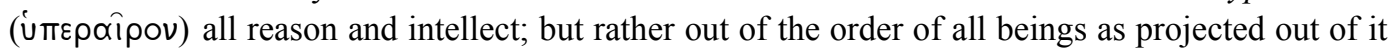
and as having some likenesses and similarities to its divine paradigms, we approach, as far as we

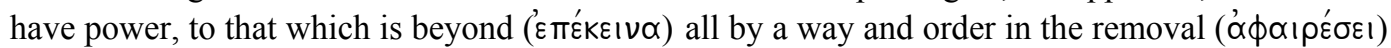

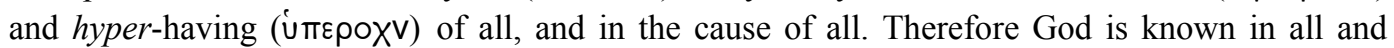
apart (Xwpis) from all (DN 7.3, 869D-872A).

In this passage Dionysius says that one of the two ways of approaching God not only removes properties of God but also interprets these removed properties hyperochically (rather than steretically). He says that aphairesis itself states preeminence. Thus he effectively says that removed properties should be interpreted apophatically.

Second, Dionysius twice conjoins the terms aphairesis and hyperoche together in the phrase hyperoche aphairesis.

It is permissible for no one who is a lover of the truth hyper all truth to hymn the thearchic hyperbeingness - whatever is the hyper-subsistence (uாєрú $\pi \alpha \rho \xi \mid S)$ of the hyper-goodness - as word,

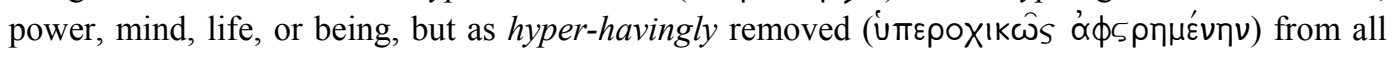
condition, motion, life, imagination, opinion, name, word, thinking, intellection, being, rest, foundation, unity, limit, non-limit, and whatever else has being ( $D N 1.5,593 \mathrm{C})$.

As we showed in the Theological Outlines with many examples from the sacred writings, the things unified of the whole divinity are the hyper-good, the hyper-god, the hyper-being, the hyper-

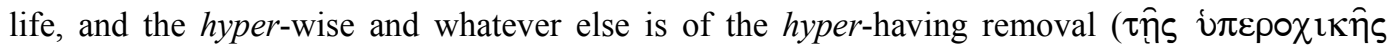
$\dot{\varepsilon} \sigma \tau \imath \nu \grave{\alpha} \phi \alpha \iota p \dot{\varepsilon} \sigma \varepsilon \omega \varsigma)[\ldots](D N 2.3,640 \mathrm{~B})$.

In these passages Dionysius indicates that aphairesis states hyperochic preeminence. To remove from God condition, motion, and life is to interpret these properties hyperochically, just as to name God as hyper-good, hyper-god, and hyper-being is implicitly to remove these names (in their non hyper-prefixed form) with respect to being. To aphairetically remove in a hyperochic manner is therefore to remove apophatically.

16. It is also so since Dionysius uses hyperoche ambiguously. See, for example, $D N 12.4,972 \mathrm{AB} ; D N 11.1$, 949AB; EP 5, 1073A; EP 9.5, 1112C; $C H$ 13.4, 304C; $D N 7.1,865 \mathrm{~B}$.

17. For Dionysius' claim that causes do not participate in their effects, see $D N 2.8,645 \mathrm{D} ; D N 4.7,701 \mathrm{C}-704 \mathrm{~A}$; $D N$ 9.6, 913CD. (Note, though, that $D N 2.6,644 \mathrm{BC}$ indicates that divine names themselves give themselves whole and the same to that which participates in them.). And here are Dionysius' terminological varieties of precontainment: pro-hyparxis (DN 4.10, 708B); pro-hypostasis ( $D N 1.4,592 \mathrm{D} ; D N 4.7,704 \mathrm{~A}$; $D N 4.12,709 \mathrm{D}$; $D N$ 5.5, 820B; $D N$ 5.6, 820D; $D N$ 5.8, 824C, $D N$ 6.3, 857B; $D N$ 7.2, 869B); pro-(en)eimi (DN 2.8, 645D; $D N$ 4.14, 712C; $D N$ 5.5, 820A; $D N$ 5.5, 820B; $D N$ 5.8, 821D; DN 5.8, 824A; EP 9.5, 1112C), pro-echō (DN 1.6, 596B; $D N 2.10,648 \mathrm{C} ; D N 4.6,701 \mathrm{~B} ; D N 4.7,704 \mathrm{~A} ; D N 5.5,820 \mathrm{~B} ; D N 5.8,824 \mathrm{~B} ; D N 5.9,825 \mathrm{~A} ; D N 5.10$, 825B; $D N$ 7.2, 869B; $D N$ 8.2, 889D; $D N$ 8.6, 893C; $D N$ 9.4, 912C; $D N$ 13.1, 977B), prolambanō (DN 1.4, 
593A; $D N 1.5,593 \mathrm{~A} ; D N$ 1.7, 597A; $D N$ 4.12, 709B; $D N$ 5.4, 817D; $D N$ 5.8, 824B; $D N 5.8,824 \mathrm{C} ; D N 7.2$, 869A; $D N 7.2,869 \mathrm{~B} ; D N 7.4,872 \mathrm{C} ; D N 9.10,917 \mathrm{~A} ; D N 13.3,980 \mathrm{~B})$.

18. When Dionysius needs to differentiate between divine names qua causes and divine names qua effects, he does it the way any good Platonist would - by auto-prefixing the divine names qua causes (see, for example, $D N$ 2.8, 645CD; $D N$ 5.5, 820B; $D N$ 5.5, 820BC; $D N$ 11.6, 953C-956B). In fact, Dionysius sometimes employs three different grammatical devices to designate three different respects of divine names: divine names are prefixed with hyper (beyond) to refer to them as they are precontained in and substanced out of God prior to or independent of their causal roles; they are prefixed with auto (itself) to refer to them as causes apart from the participation of beings in them; and they are suffixed with ōsis (making) - or, less frequently, poiēsis (producing), gonos (begetting), or dōros (giving) - to refer to them as they actually flow forth to participating beings. $D N 11.6$ is the most sustained treatment of these distinctions. But for passages that auto-prefix divine names, see also $D N$ 2.1, 636C; $D N$ 2.8, 645D; $D N$ 4.16, 713C; $D N$ 4.21, 724C; $D N$ 5.5, 820ABC; $D N$ 6.1, $825 \mathrm{C} ; D N 6.1,856 \mathrm{~B} ; D N 6.2,856 \mathrm{C} ; D N 6.3,857 \mathrm{C} ; D N 7.1,865 \mathrm{~B}, 868 \mathrm{~A} ; D N$ 8.2, 889D; $D N$ 9.6, 916A; $D N$ $9.10,917 \mathrm{~A} ; D N 11.2,949 \mathrm{C}$. And for passages that refer to particular divine names as the sources or causes of particular properties, see also $D N 4.1,693 \mathrm{~B} ; D N 4.4,697 \mathrm{CD} ; D N 4.7,701 \mathrm{C} ; D N 4.12,709 \mathrm{CD} ; D N 5.1,816 \mathrm{~B}$; $D N$ 5.2, 816C; $D N$ 6.3, 857B; $D N$ 7.1, 868A; $D N$ 8.7 83D-896A; $D N$ 8.9, 896D; DN 9.6, 913D; $D N$ 9.8, 916B; $D N 10.3,940 \mathrm{~A} ; D N 11.1,948 \mathrm{D}-949 \mathrm{~A} ; D N 12.4,972 \mathrm{AB} ; D N 13.2,977 \mathrm{C}-980 \mathrm{~A}$. And for other uses of $\overline{o s i s-}$, poiessis-, gonos-, and dōros-suffixed divine names, see also $D N 2.4,640 \mathrm{D} ; D N 2.5,641 \mathrm{D}-644 \mathrm{~B} ; D N 2.7$, 645A; DN 2.11, 649AB, 652A; DN 4.7, 701C; DN 11.6, 956AB.

19. Plenty of passages attribute causal activity of the Dionysian God. Consider, for example, the following four: $\mathrm{CH} 4.1,177 \mathrm{C}$ declares that the hyper-being thearchy hypostatizes the beings of all beings, bringing them into being; EH 3.III.4, 429C says sacred scripture teaches, among other things, the generated constitution and order of things from God; $D N 1.3,589 \mathrm{C}$, "speaking simply," asserts that God is the source and cause of every life and being; and DN 8.2, 889D-892A makes it clear that even though God is in some sense before and beyond power, God is still the cause of every power. Moreover, not a single passage denies causal activity of the Dionysian God. Not even in the concluding chapters of the Mystical Theology (chs. 4-5), wherein Dionysius removes every ostensibly conceivable property from God, does Dionysius remove from God any variation of aitia (cause), archē (source/principle), hypostasis (substance, give substance to), or hyparxis (constitute, make subsist). In fact, all the properties that are removed in these chapters are removed from a God that is said to be at once "cause of all and being hyper all." Further, even when Divine Names 1.5 predicates thearchy itself as hyper-hyparxis, it goes on to say that this hyper-hyparxis thearchy is the hyparxis of goodness and hypostasis of the whole $(D N 1.5,593 \mathrm{CD})$. And further still, although nine passages in the corpus prefix arche with hyper (DN 1.3, 589D; DN 4.10, 708A; DN 11.6, 953D-956A; CH 1.2, 121B; CH 7.4, 212C; CH 9.1, 257B; CH 10.1, 273A; $C H$ 13.4, 304C; EP 2, 1069A), none calls into doubt the claim that God is cause and source of all (and all but one employ some variation of the phrase hyper-source source, thereby suggesting that the hyper-being God is a source that is preeminent to ordinary sources, i.e., a hyper-being source).

20. When Dionysius does remove divine names from God in Mystical Theology 5, what he removes is only the properties that the divine names themselves source, not the divine names themselves. This is so for three reasons. Syntactically, these terms are not auto-prefixed (as divine names themselves often are). Semantically, these terms are referred to as "beings" (and therefore cannot refer to divine names themselves, which are hyper being), and also seem to be of a similar logical type as the perceptible symbols removed in the preceding chapter (which, unlike divine names, do not possess a causal respect). And logically, as mentioned above, if divine names themselves are removed from God then causality itself must be removed from God; but causality itself is not removed from God; so the divine names themselves cannot be removed from God.

21. Laurence Horn, explicating the position of Otto Jespersen, provides the following example of an excluded nonmiddle: If someone believes that War and Peace is an excellent book, she may in certain circumstances deny both that War and Peace is a good book (since it is more than just good) and that War and Peace is not a good book (since it is not a bad book) [10], p. 204. See here Horn's treatment of scalar predication (pp. 204-267). But note that Horn believes scalar predicates are pragmatically, not semantically, ambiguous - i.e., in certain contexts they can be used to mean "exactly $p$ " rather than "at least $p$ " (pp. 243, 250, 266-267).

22. Another way of understanding hyperochē mind is as mind hyper being (or hyper-being mind, or hyper-mind mind, or mind hyper-mind - Dionysius uses all such combinations). It's not surprising, then, to find Dionysius not only making frequent and key use of the adverb hyperbeingly and the formula hyper-dn dn (e.g., hyperbeing being, goodness hyper-good) but also objecting to the application of things of being both to the divine names themselves and to the persons of the Trinity. For uses of hyperbeingly, see $D N 1.3,589 \mathrm{C} ; D N 2.10$, 
648CD; $D N 2.11,649 \mathrm{BCD} ; D N$ 4.7, 704B; $D N$ 5.8, 824AB; $D N$ 9.8, 916B; $D N$ 11.6, 953C; $D N$ 13.3, 980BC; $D N$ 13.3, 980D-981A; CH 7.4, 212D; CH 9.4, 261D; $M T$ 1.2, 1000A; EP 1, 1065A; EP 4, 1072AB. For uses of hyper- $d n d n$ formulas, see $D N 1.1,588 \mathrm{~B} ; D N 1.3,589 \mathrm{C} ; D N 2.4,641 \mathrm{~A} ; D N 2.11,649 \mathrm{C} ; D N 4.7,704 \mathrm{~A} ; D N$ $5.1,816 \mathrm{~B}$. And for objections to the application of things of being to that which is hyper being, see the following: $D N 2.7,645 \mathrm{AB} ; D N 7.1,865 \mathrm{C}-868 \mathrm{~A} ; D N 7.3,869 \mathrm{C}-872 \mathrm{~A} ; D N 11.1,949 \mathrm{AB} ; D N 13.3,981 \mathrm{~A} ; M T$ 1.1, 997B-1000A; MT 1.2, 1000AB; CH 2.3, 140D-141A; CH 13.4, 261C; MT 2, 1025AB; EP 1, 1065AB; EP $5,1073 \mathrm{~A}-1076 \mathrm{~A}$.

23. If space permitted, I would argue on behalf of a modified-Searlean fourfold typology of illocutionary force, one that recognizes (1) that assertives as well as expressives possess a word-to-"world" direction of fit and therefore have their foundation in the intentional state of perception, (2) that directives and commissives have a world-to-word direction of fit and therefore have their foundation in the intentional state of action, and (3) that expressives and commissives both concern the self whereas assertives and directives both concern the world/other; and (4) that declaratives do not constitute a distinct type (but rather function as a subtype of each of the four main types). This is how I render this typology in tabular form:

\begin{tabular}{|l|l|l|}
\cline { 2 - 3 } \multicolumn{1}{c|}{} & Target $=$ external/other & Target $=$ internal/self \\
\hline Fit = word-to-“world" & Assertive & Expressive \\
\hline Fit = world-to-word & Commissive & Directive \\
\hline
\end{tabular}

24. The critical edition of the Dionyaisn corpus lists 6 occurrences of nameless (DN 1.1, 588B; DN 1.6, 596A (3 occurrences); $D N$ 1.7, $596 \mathrm{C} ; D N 7.1,865 \mathrm{C}), 11$ occurrences of unspeakable (DN 1.1., 585B (2 occurrences); $D N$ 2.4, 641A; $D N$ 2.5, 641D; $D N$ 2.10, 648D; $D N$ 2.10, 649A; $D N$ 6.3, 857B; $D N$ 8.2, 892A; $D N 11.1$, 949B; $C H 4.4,181 \mathrm{~B} ; M T$ 3, 1033C), and 21 occurrences of ineffable (DN 1.1, 588B (2 occurrences); DN 1.3, 589B; $D N 1.4,592 \mathrm{~A} ; D N 1.5,593 \mathrm{~B} ; D N 2.6,644 \mathrm{C} ; D N 2.9,648 \mathrm{~A} ; D N 2.10,648 \mathrm{D} ; D N 3.3,684 \mathrm{~B} ; D N 5.1$, 816B; $D N 7.1,865 \mathrm{C}$ (2 occurrences); $D N 11.5,953 \mathrm{~B} ; D N 13.3,981 \mathrm{~A} ; C H 2.3,141 \mathrm{~A} ; C H$ 15.9, 340A; EH 2.I, 392B; EH 2.III.8, 404D; EH 4.III.10, 484A; EP 3, 1069B; EP 9.1, 1105D. A Thesaurus Linguae Graecae search confirms these and also finds 27 occurrences of logos-less (alogos).

25. Both cases occur at $M T 5,1048 \mathrm{AB}$.

26. Perhaps then their psychological conditions are also impossible to express since expression of one's belief in the ineffability of God would require being able to identify God in some way.

27. There are four occurrences of hyper position and removal in the Dionysian corpus: DN 2.4, 641B; MT 1.2, 1000B; MT 3, 1033CD; MT 5, 1048A-1048B.

28. The register of the critical edition of the Dionysian corpus lists 4 instances of hyper-ineffable (hyperarrētos $D N 1.4,592 \mathrm{D} ;$ DN 2.4, 640D; $C H$ 13.4, 304C; EP 7.2, 1080C).

29. See here especially [9] and [18].

30. Even better, the hyper-being God is (a) sayable qua being through the "position of all" the properties that the divine names themselves source; (b) unsayable qua being through the "removal of all" the properties that the divine names themselves source; and (c) sayable hyper being as the hyper-existent and hyper-unified divine names themselves, which are "hyper all position and removal" insofar as position and removal are of things of being. And note that this saying hyper being is, technically speaking, not a saying at all, since all saying is of things of being. Thus it is a silent saying, a saying beyond $\log o s$ (e.g., MT 3, 1033BC; DN 1.3, 589AB). Still, it is a communicative something that makes possible the transmission of hyper-nous knowledge of divine things.

31. Another, initially plausible solution is that of taking Dionysius' ineffability assertions as second-order assertions about first-order assertions about God. One problem with this solution, though, is that it renders God in some small way effable from the perspective of being. Another problem with this solution is that it fudges passages that indicate that the hyper-being God is both ineffable and transcendently effable.

32. In addition to the passages quoted below, see $M T 1.3,1000 \mathrm{C}$; and $D N 13.3,981 \mathrm{AB}$.

33. A good many of the passages that speak of God as ineffable or unknowable explicitly state not only that such ineffability-unknowability is due, at least in part, to human limitation but also that it can be - indeed, is overcome through divine revelation through the celestial and ecclesiastical hierarchies. This is a common motif in the opening chapter of the Divine Names, a chapter that is often said to concern the problem of naming an utterly ineffable and unknowable God. Instead, Dionysius indicates right from the get-go not only that ineffable-unknowable things may be known through divine revelation but also that they are so known in a state of union that surpasses our ordinary rational and intellectual powers. 
And now, O blessed one, after the Theological Outlines I will proceed to the explication of the divine names as far as I am able. And now let the law of the scriptures, which limits us beforehand, bind us fast to the truth of what is said about God, "not in persuasive words of human wisdom, but in demonstration" of the spirit-moved "power" of the theologians, by which we are

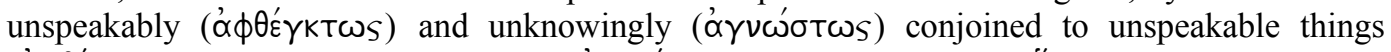

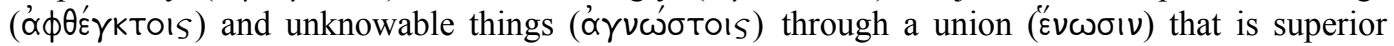

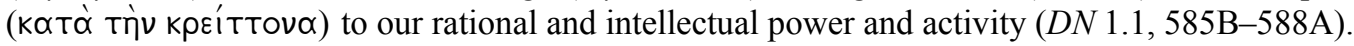

The second paragraph of Divine Names 1.1 then picks up and develops these themes.

Therefore, in general one must dare neither to say nor, indeed, to conceive anything about the hyper-being and hidden divinity over and above that which has been divinely revealed to us in the sacred scriptures. For one must attribute to the hyper-beingness unknowing (which is hyper speech

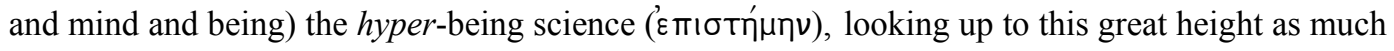
as the ray of the thearchic scriptures gives itself, drawn together to the higher splendors by temperance and piety for the divine things. For if one must trust the all-wise and most-true theology, the divine things are revealed and contemplated, according to the analogy of each of the minds, of the thearchic goodness, which divinely distributes the immeasurable (as that which cannot be contained) in saving justice of those things that are measured (DN 1.1, 588A).

Here we are first told that the hyper-being and hidden divinity has been revealed in the sacred scriptures, but that we are not to say or conceive anything about it over and above this revelation. Then we are told that we must attribute to this hyper-beingness unknowing, which is hyper speech and mind and being, a hyper-being science (epistèmē). Clearly, then, the fact that God is a hyper-being and hidden divinity, a hyper-beingness unknowing hyper logos and intellect and being, is not the end of the story for human knowability and effability about God. For this hyper-being and hidden divinity is revealed in the sacred scriptures, which are a hyperbeing "science" of divine things. And it is revealed, as the last sentence tells us, in accordance with the analogical position of our intellect. Although humans cannot know the hyper-being God through their natural rational-intellectual powers, they can know God in divine revelation by means of power that exceeds these powers. See the rest of Divine Names 1, especially DN 1.2 and 1.4, for more.

34. The preparatory conditions of a direction are two: (1) Hearer is able to do the action, and speaker believes the hearer is able to do the action; (2) It is not obvious to both speaker and hearer that hearer will do the action in the normal course of events of the speaker's own accord [25], p. 66.

35. The register of the critical edition of the Dionysian corpus lists 4 instances of hyper-unknowable (hyperagnōstos - DN 1.4, 592D; DN 1.5, 593B; DN 2.4, 640D; MT 1.1, 997A). Thesaurus Linguae Graecae reveals an additional occurrence of hyperagnotatēs at $\mathrm{CH} 10.3,273 \mathrm{C}$. Note that Dionysius never says that God is hyper not-removal or not-position.

36. See the discussion of MT 1.3's phrase "according to what is greater" in [7]. For sources that identify the reference of this phrase with a certain hyper-nous faculty in humans, see also [28], [22], [1].

37. For my argument that the hymns of the Mystical Theology probably served a theurgical role in the liturgy, see my forthcoming paper [13]. And for more on hymns as theurgic devices, see [27].

38. Consider here the uses of now in MT 3, 1033BC:

I think you have noticed how the last things are more wordy than the first things; for it is necessary that the Theological Outlines and the unfolding of the Divine Names are less wordy than the Symbolic Theology. Since the more we look upward, the more words are constricted by the synopsis of the intelligibles; just as now, entering into the hyper mind darkness, we will find not few-words but rather complete a-logos and unknowing. Descending from what is above to the last things, the logos widens according to the measure of the descent with analogical multitude/number. But now, ascending from what is below to that which hyper-lies, [the logos] is shortened according to the measure of ascent and, after all ascent, is wholly soundless and wholly united to the unspeakable.

39. Although Searle believes there is no "algorithm" for calculating the value of a metaphorical utterance (p. 149), he does provide eight "principles" for computing metaphorical meaning, six of the more notable of which 
follow: (1) Things which are P are by definition R; (2) Things which are P are contingently R; (3) Things which are $\mathrm{P}$ are often said or believed to be R; (4) Things which are P are not R, nor are they like R things, nor are they believed to be $\mathrm{R}$; nonetheless it is a fact about our sensibility, whether culturally or naturally determined, that we just do perceive a connection, so that $\mathrm{P}$ is associated in our minds with $\mathrm{R}$; (5) $\mathrm{P}$ things are not like $\mathrm{R}$ things, and are not believed to be like $\mathrm{R}$ things; nonetheless the condition of being $\mathrm{P}$ is like the condition of being R; (6) There are cases where P and R are the same or similar in meaning, but were one, usually $\mathrm{P}$, is restricted in its application, and does not literally apply to $\mathrm{S}$ (pp. 107-112).

40. Lakoff and Johnson speak of metaphors as conventionally fixed means of understanding and experiencing one kind of thing in terms of another, they use the term quite broadly, denying any substantial difference between novel and lexicalized metaphors [15, 66-70]. It is here that Lakoff and Johnson's work is at its weakest as it fails to give an adequate explanation of the production and comprehension of novel, complex metaphors (as well as the lexicalization of novel metaphors).

41. Thus although Lakoff and Johnson do not think that primary metaphors are innate, they do state that there appears to be "at least several hundred such widespread, and perhaps universal, metaphors" [15, p. 57].

42. Complex metaphors are also composed of "commonplace knowledge" (cultural beliefs, empirical facts, etc.) [15], p. 60.

43. According to Lakoff and Johnson, abstract concepts have two parts: "(1) an inherent, literal, nonmetaphorical skeleton, which is simply not rich enough to serve as a full-fledged concept; and (2) a collection of stable, conventional metaphorical extensions that flesh out the conceptual skeleton in a variety of ways (often inconsistently with one another)" (p. 128).

44. Lakoff and Johnson speak instead of the "natural dimensions" of human experience, which, in the case of concepts pertaining to action, activity, event, and experience are the "component parts" listed above [14, p. $176]$.

45. In fact, Lakoff and Johnson believe that most concepts require multiple metaphorical structurings insofar as no one metaphor is extensive and supple enough to "do the job" [14, p. 95].

46. And when two different metaphors do not possess overlapping entailments, "mixed metaphors" result (p. 95).

47. This said, a couple of caveats are in order. First, in referring to these concepts or predicates as metaphors, I want to be clear that I do so in the Lakoff-Johnsonian sense of cross-domain mappings that employ direct sensorimotor experiences (darkness, height) to conceptualize and speak about subjective experiences (unknowing) or abstract concepts (God); put differently, these mappings are semiotically codified; they constitute (in most cases) conventionally-established, literally-coded meanings of their respective terms (even if not their primary or original meanings), not novel metaphors. Second, if we are to speak about these conventionalized, cross-domain mappings as metaphors, we must be careful not to think that they do not make (literal) truth-claims about their subjects. It is hard to know how to read Lakoff and Johnson on this point: although they oppose the reduction of metaphors to literal language, the fact that they map a subjective judgment such as unknowing to a sensorimotor experience such as darkness seems to entail that darkness can be reduced to unknowing (along with an accompanying gestalt and set of entailments) ([15], p. 122); and although they assail a correspondence theory of truth, the fact that metaphorical truth rests on true judgments about sensorimotor experience seems to presuppose some sort of correspondence theory of truth (as do the three assertions with which they begin Philosophy in the Flesh: the mind is inherently embodied; thought is mostly unconscious; abstract concepts are largely metaphorical) (p. 128, 3).

48. This metaphor is also reinforced by Dionysius' use of metaphors of light - the contrary of darkness - to symbolize knowing. (Although Dionysius chiefly uses metaphors of light (sun, fire) as symbols for God's causation and illumination of celestial and terrestrial beings, he says in the Celestial Hierarchy that fire is an appropriate symbol for God for a number of other reasons (e.g., omnipresence, invisibility, inexorability, power, dynamism; $\mathrm{CH}$ 15.2, 329ABC). Celestial Hierarchy 13.3, after explicitly using the light of the sun and the heat of fire as symbols for knowledge, declares that God is really and properly by nature the source of illumination ( $\mathrm{CH} 13.3,301 \mathrm{D})$. And although Divine Names $4.1-4$ tends to use light more broadly as a symbol for all divine procession, Divine Names 4.5-6 narrows the meaning of light to that of knowledge. Moreover, still other passages oppose light to darkness as contrary symbols for knowing and unknowing, respectively. Epistle 1 says that darkness disappears in the light just as unknowing is removed by light $(E P 1,1065 \mathrm{AB})$. And the above passage from Mystical Theology 1.3 indicates that Moses enters the divine darkness of unknowing only after passing beyond "the many pure lights that flash forth and the greatly-flowing rays" (MT 1.3, 1000D). 
49. For the first and second metaphors (similarity is proximity, intimacy is proximity), see [15], pp. 51, 50; and [8], pp. 283, 293. And for the fourth metaphor (degree is distance along a path), see [8], p. 285. Although I cannot find the third metaphor (knowledge is proximity) in either of these sources, it seems obviously primary insofar as the sensorimotor experience of getting closer to something is constantly conjoined with the subjective experience of better knowing what that thing is.

50. According to Lakoff and Johnson, understanding is grasping and seeing is touching are also part of this family of metaphors ([15], p. 54). Interestingly, these metaphors also have a phonetic manifestation: the rising intonation used in questions, and the falling intonation used in statements ([14], p. 137).

51. Note that Lakoff and Johnson do not provide an experiential basis for good is up. They do however say that the primary experience of another related metaphor, important is big, is the realization that big things (e.g., parents) are important and can exert major forces on a child and dominate a child's visual experience (p. 50).

52. According to Lakoff and Johnson, the more is up and unknown is up metaphors "have a very different experiential basis" ([14], p. 21).

53. For more on the notion of an isotopy, see [6] and [5]. Isotopies are the semantic properties of texts that make possible their disambiguation through abductive inferences known as topics. Put differently, topics are pragmatic devices used to by readers to identify the semantic properties of texts called isotopies. Thus topics make possible the uniform readings of stories. As such, Eco understands isotopy to be "an umbrella term," a general category under which various parallel (autonomous yet interactive) levels of textual coherence or sense can be subsumed ([5], p. 189). Of the eight isotopies that Eco provides in Semiotics and the Philosophy of Language, the one that is most useful to a disambiguation of Dionysian metaphors of darkness and height is narrative isotopies connected with discursive isotopic disjunctions that generate complementary stories, since it provides a way of reconciling apparent conflicts at a discursive level simply by showing how such disjunctions generate a complementary story at the level of the text. 